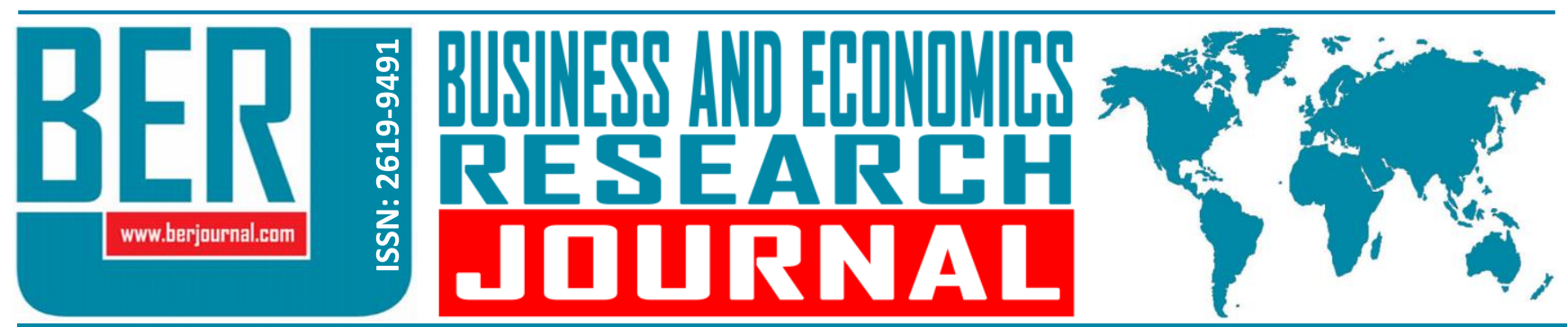

Business and Economics Research Journal Vol. 9, No. 2, 2018, pp. 331-348 doi: 10.20409/berj.2018.108

\title{
Entelektüel Sermayeyi Hesaplanmış Maddi Olmayan Değer Yöntemi İle Ölçme ve Raporlama*
}

\author{
Selim Yuksel Pazarceviren ${ }^{a}$, H. Pinar Kaya ${ }^{b}$
}

Öz: Entelektüel sermayeyi ölçmeye ve raporlamaya yönelik yapılan çalışmaları inceleyerek muhasebe bakış açısıyla değerlendirmek ve Borsa İstanbul'da Dokuma, Giyim Eşyası ve Deri Sektörü'nde faaliyet gösteren işletmelerin 2014, 2015 ve 2016 yıllarına ait entelektüel sermaye değerlerini "Hesaplanmış Maddi Olmayan Değer Yöntemi" kullanarak tespit etmek çalışmanın temel amaçlarını oluşturmaktadır. Elde edilen bulgulara göre, işletmelerin gerçek değerini gösteren entelektüel sermayenin raporlanması gerektiği ifade edilebilir. Ancak Uluslararası Finansal Raporlama Standartları'nda ve Türkiye Muhasebe Standartları/Türkiye Finansal Raporlama Standartları'nda entelektüel sermayeye yönelik olarak doğrudan yapılmış bir düzenleme bulunmaması, entelektüel sermayenin maddi olmayan duran varlık olarak muhasebeleştirilmesini ve finansal tablolarda raporlanmasını güçleştirmektedir. Bu çalışma mevcut düzenlemeler çerçevesinde entelektüel sermayeye ilişkin bilgilerin işletmelerin yıllık faaliyet raporlarında sunulmasının en doğru raporlama yaklaşımı olduğunu ortaya koymuştur.

\section{Measurement and Reporting of Intellectual Capital with Calculated Intangible Value Method}

\begin{abstract}
The main purposes of this study are to examine the studies measuring and reporting intellectual capital, to revise these studies with accounting perspective and to determine the intellectual capital values of firms operating in Textile and Leather Products Industry in Borsa Istanbul for the years 2014-2016 via "Calculated Intangible Value Method". The findings reveal that intellectual capital indicating firms' fair value is to be reported. However, it is difficult to recognize intellectual capital as an intangible asset and to report it in financial tables since there is not a direct definition towards intellectual capital in International Financial Reporting Standards and Turkish Accounting Standards/Turkish Financial Reporting Standards. This study reveals that the best reporting approach is to present the information related with intellectual capital in the annual reports of firms within the frame of current regulations.
\end{abstract}

Anahtar Sözcükler:

Entelektüel Sermaye, Bilgi, Hesaplanmış Maddi Olmayan Değer Yöntemi, Maddi Olmayan Duran Varlık, Finansal Raporlama

JEL: M40, M41

Geliş: 31 Ocak 2018 Düzeltme: 8 Mart 2018 22 Mart 2018 Kabul: 23 Mart 2018

Keywords: Intellectual Capital, Knowledge, Calculated Intangible Value Method, Intangible Asset, Financial Reporting

JEL: M40, M41

Received: 31 January 2018 Revised: 8 March 2018 22 March 2018

Accepted: 23 March 2018

a Prof., PhD., Istanbul Commerce University, Faculty of Business Administration, Department of Accounting and Auditing, Istanbul, Turkiye, spazarceviren@ticaret.edu.tr (ORCID ID: 0000-0001-8198-4424)

b Asst. Prof., PhD., Ahi Evran University, Faculty of Economics and Administrative Sciences, Department of Business Administration, Kirsehir, Turkiye, pkaya@ahievran.edu.tr (ORCID ID: 0000-0002-8736-088X)

* Bu çalışma 2008 yılında H. Pınar KAYA tarafından Sakarya Üniversitesi Sosyal Bilimler Enstitüsü Iş̧letme Anabilim Dalı MuhasebeFinansman Tezli Yüksek Lisans Programı'nda Prof. Dr. Selim Y. PAZARÇEViREN danışmanlığında hazırlanmış olan “Entelektüel Sermayenin Finansal Tablolar Aracılığıyla Sunulması Sorunu ve Çözüm Önerileri” başlıklı yüksek lisans tezinden üretilmiştir. 


\section{Giriş}

Entelektüel sermaye özellikle muhasebe, finans ve yönetim alanında çalışan akademisyenlerin farklı açılardan ele aldıkları ve yoğun ilgi gösterdikleri konulardan biridir. Önceki dönemlerde maddi varlıklara yatırım yapan ve sermaye yapılarını güçlendiren işletmeler rekabet avantajı elde ederken, günümüzde bilgi teknolojisinde yaşanan gelişmelerle birlikte maddi olmayan varlıklara yatırım yapan işletmeler daha avantajlı hale gelmiştir.

Türkiye Muhasebe Standartları'na göre maddi olmayan duran varlık olma şartını sağlamayan ancak işletmelerin piyasa değerleri ile defter değerleri arasındaki farkı açıklamada kullanılan entelektüel sermayenin objektif bir şekilde ölçülmesi ve raporlanması, işletmenin gerçek değerinin kaynağını bilmek isteyen bilgi kullanıcıları açısından bir ihtiyaçtır. Literatürde yer alan çalışmalarda entelektüel sermayenin ölçülmesi için farklı yöntemler kullanılmış ve entelektüel sermayenin raporlanmasına yönelik çeşitli yaklaşımlar ortaya konmuştur. Ancak tüm çabalara rağmen, entelektüel sermayenin ölçümü ve raporlanması hususunda genel kabul görmüş bir standart geliştirilememiştir.

Çalışmanın amacı, işletme içinde ve dışında yer alan tüm bilgi kullanıcıları için önemli olan entelektüel sermaye değerinin ölçümüne ve raporlanmasına yönelik literatürde yer alan farklı yaklaşımları değerlendirmek ve işletmelerin entelektüel sermayeden yararlanma gücünü uygulamalı bir şekilde ortaya koyarak, genel bir sonuca ulaşmaktır.

Çalışma kapsamında öncelikle entelektüel sermayeye ilişkin genel bir kavramsal çerçeve oluşturulacaktır. Devamında, entelektüel sermayenin ölçümünde kullanılan yöntemlere ve raporlanmasına yönelik bilgiler verilecektir. Literatürde yer alan çalışmalar incelendikten sonra Borsa İstanbul'da Dokuma, Giyim Eşyası ve Deri Sektörü'nde faaliyet gösteren işletmelerin entelektüel sermaye değerleri “Hesaplanmış Maddi Olmayan Değer Yöntemi" kullanılarak hesaplanmaya çalışılacaktır. Elde edilen bulgular değerlendirilerek, çalışma tamamlanacaktır.

\section{Kavramsal Çerçeve}

Değişime uyum sağlamak, işletmelerin varlıklarını devam ettirebilmelerinin önşartlarından biridir. Bilginin önemli bir güç kabul edildiği günümüzde, fiziksel ve finansal sermayeye sahip olmakla birlikte sürdürülebilir bir rekabet avantajı elde etmek isteyen işletmelerin, entelektüel sermaye olarak adlandırılabilen bilgi temelli varlıklara yönelmeleri beklenir hale gelmiştir (Pereira ve Santos, 2017: 351). Işletmeleri geleceğe taşıyacak olan unsurların; çalışanlar, onların yarattığı değer, şirket stratejisi ve yapısı, sistem ve süreçler, müşteriler ve toplumla kurulan ilişkiler toplamından oluşan "entelektüel sermaye" olduğu (Erkal, 2006: 41) düşünülmektedir.

Entelektüel sermaye kavramının birçok yazar ve akademisyen tarafından çok çeşitli tanımı yapılmıştır. Yapılan tanımlardan bazıları şunlardır:

“iş̧letmenin, kullanıldıkça değer kazanan ve tükenmeyen yakıııdır” (Çalışkan, 2015: 123).

"Zeka, bilgi, yaratıcılık, enformasyon, deneyim, hayal, iletişim ve etkileşim bağlamında zenginlik üreten mekanizmadır" (Acar ve Dalğar, 2005: 25).

"Mayasını bilgi, beceri, deneyim ve enformasyonun oluşturduğu, işletmenin mevcut ve gelecekteki başarısını doğrudan etkileyen ve rakip firmalarla kıyaslamada konumunu ortaya koyan sahip olduğu bilgi, bilgi sistemleri, patent, telif hakları ve lisans anlaşmaları gibi maddi olmayan (soyut) varlıkların bütünüdür" (Çıkrıkcı ve Daştan, 2002: 20).

"Şirket ağacını besleyen, onu yetiştiği toprak olan sektör ortamına sıkıca bağlayan, ama görünür olmaktan uzak olan köklerdir" (Bilmedik, 2013).

"Işletmenin hisse senetlerinin piyasa fiyatı toplamı ile hisse senetlerinin defter değerleri toplamları arasındaki farktır" (Aşıkoğlu ve Aşıkoğlu, 1998: 585). 
Tanımlardan da anlaşılacağı gibi, entelektüel sermaye işletmelerin kendi içlerinde oluşturdukları sinerjinin, değere dönüştürülerek işletme lehine kullanılmasıdır. Değer yaratabilen işletmelerin defter değerlerinin çok üzerinde piyasa değerine ulaşmış olmaları (Hobikoğlu, 2011: 87) bu sonucu doğrular niteliktedir.

İşletme değerinin muhasebe sistemine ve piyasaya göre büyük farklılıklar göstermesi, tarihi maliyet esasına dayalı olan ve daha çok maddi varlıklara ağırlık veren bir muhasebe sisteminin ürettiği finansal tabloların, finansal tablo kullanıcılarının bilgi ihtiyacını karşılayamadığı açıktır (Çıkrıkçı ve Daştan, 2002: 18). Bu sebeple işletme içindeki potansiyel enerji ve kollektif beyin gücünden meydana geldiği ifade edilen maddi olmayan varlıklara (Erkal, 2006: 19) ilişkin bilgilerin önemlilik düzeyi yüksektir.

Maddi olmayan varlık olarak nitelendirilen entelektüel sermayeyi iyi anlayabilmek için hangi bileşenlerden oluştuğunu ve bileşenleri arasındaki ilişkiyi bilmek gereklidir. Entelektüel sermayenin en genel kabul görmüş unsurları ya da bileşenleri; insan sermayesi (human capital), yapısal sermaye (structural capital) ve ilişkisel sermaye (relational capital) olmak üzere üç grupta toplanır (Pereira ve Santos, 2017: 352). Entelektüel sermayenin bileşenlerine ilişkin özet bilgiler aşağıdaki Şekil 1'de sunulmaktadır:

Şekil 1. Entelektüel Sermaye Bileşenleri

\begin{tabular}{|c|c|c|}
\hline & Entelektüel Sermaye Bileşenleri & \\
\hline İnsan Sermayesi & Yapısal Sermaye & İlişkisel Sermaye \\
\hline $\begin{array}{l}\text { - Çalışanların Mesleki Bilgisi } \\
\text { - Çalışanların İş Deneyimi } \\
\text { - Çalışanların Takım Çalışması } \\
\text { Yapabilme Yeteneği } \\
\text { - Çalışanların Yaratıcılığı } \\
\text { - Çalışanların Öğrenme Yeteneği }\end{array}$ & $\begin{array}{l}\text { - Organizasyon Yapısı ve Kültürü } \\
\text { - Süreç ve Sistemler } \\
\text { - Veri Tabanları ve Belgeleme } \\
\text { Hizmeti } \\
\text { - Bilgi Teknolojilerinin Kullanımı } \\
\text { - Patentler ve Telif Hakları }\end{array}$ & $\begin{array}{l}\text { - Marka İmajı ve Kurumsal İmaj } \\
\text { - Satıcı İlişkileri } \\
\text { - Müşteri İlişkileri } \\
\text { - Diğer İşletmelerle iliş̧kiler } \\
\text { - Pazar payı } \\
\text { - Franchising ve Lisans Anlaşmaları }\end{array}$ \\
\hline
\end{tabular}

Kaynak: Bontis, 2001: 45; Arslan, 2004: 82-83; Ulusan, 2005: 87-88.

İnsan sermayesi, işletme çalışanlarına ait özellikleri kapsar. Mesleki bilgiye ve tecrübeye sahip, takım çalışması yapabilen, öğrenmeye ve gelişime açık, yaratıı ve üretken çalışanların, işletmeye sağladığı katkıyı ifade eder. İşletme çalışanlarının eve gittiğinde, iş yerinde bıraktıkları herşey yapısal sermaye olarak adlandırılmaktadır (Bontis, 2001: 45). İşletmeleri ayakta tutan iskelet bir yapıya benzetilen yapısal sermaye, işletmelerin tamamen kontrol edebildiği ve bir bütün olarak işletmeye ait olan entelektüel sermaye bileşenidir (Eren ve Akpınar, 2004: 9). Iliş̧kisel sermaye, işletme dışında yer almasına rağmen işletme faaliyetlerini etkileyen taraflarla olan ilişkileri ifade eder. Insan sermayesinin ve ilişkisel sermayenin kalıcı niteliğe sahip olması için yapısal sermayeye dönüştürülmesi gerektiği ifade edilmektedir (Bayazıtlı, 2000: 121). Entelektüel sermaye bileşenlerinin homojen olmaması ve yapılarının karmaşık olması, entelektüel sermayeyi anlamayı zorlaştırmaktadır (Prusak, 2017: 52). Anlaşılması zor olsa da, entelektüel sermaye ve her bileşeni işletmeler açısından çok değerlidir ve sürekli geliştirilmeye açıktır.

\section{Entelektüel Sermayenin Ölçümünde Kullanılan Yöntemler}

Peter F. Drucker'in "ölçemediğinizi yönetemezsiniz" yönetim anlayışından hareketle işletmelerin sahip oldukları entelektüel sermayeyi etkin bir şekilde yönetebilmeleri için, bu değeri doğru ve güvenilir bir şekilde ölçmeleri gerekmektedir. Ancak literatürde, evrensel olarak kabul görmüş bir entelektüel sermaye ölçüm yöntemi olmadı̆̆ı (Veltri ve Bronzetti, 2015: 311) belirtilmektedir. Literatürde yer alan çalışmalar incelendiğinde, entelektüel sermayenin ölçümünde kullanılan çok çeşitli yöntemlerin iki ana başlık altında toplandığı görülmektedir. 
Entelektüel sermayenin işletme düzeyinde ölçülmesinde kullanılan yöntemler

- Piyasa Değeri ve Defter Değeri Oranı

- Piyasa Değeri ile Defter Değeri Arasındaki Fark

- Tobin'in Q Oranı

- Hesaplanmış Maddi Olmayan Değer

Entelektüel sermayenin bileşenlerine ayrılarak ölçülmesinde kullanılan yöntemler

- Dengelenmiş Skor Kartı

- Skandia Pusulası

- Maddi Olmayan Varlıklar Cetveli

- Entelektüel Sermaye Endeksi

- Teknoloji Brokeri

- Entelektüel Katma Değer Katsayısı

Entelektüel sermayeyi bileşenlerine ayırarak ölçen yöntemler, entelektüel sermaye bileşenlerinde meydana gelen değişimleri tespit etmeye yönelik olmaları sebebiyle, bu çalışmanın kapsamı dışında bırakılmıştır. Entelektüel sermayenin işletme düzeyinde ölçülmesinde kullanılan yöntemlere ilişkin karşılaştırmalı özet bilgiler aşağıdaki Tablo 1'de sunulmaktadır:

Tablo 1. Entelektüel Sermaye Ölçüm Yöntemlerine Illişkin Karşılaştırma

\begin{tabular}{|c|c|c|c|c|}
\hline Yöntemler & $\begin{array}{l}\text { Piyasa Değeri } \\
\text { ve Defter } \\
\text { Değeri Oranı }\end{array}$ & $\begin{array}{l}\text { Piyasa Değeri ile } \\
\text { Defter Değeri } \\
\text { Arasındaki Fark }\end{array}$ & Tobin'in Q Oranı & Hesaplanmış Maddi OImayan Değer \\
\hline Hesaplama & $\begin{array}{l}\text { E.S.= Piyasa } \\
\text { Değeri/Defter } \\
\text { Değeri }\end{array}$ & $\begin{array}{l}\text { E.S.= Piyasa Değeri- } \\
\text { Defter Değeri }\end{array}$ & $\begin{array}{l}\text { Q=Piyasa Değeri/ } \\
\text { Varlıkların Yerine } \\
\text { Koyma Maliyeti }\end{array}$ & $\begin{array}{l}7 \text { aşamada gerçekleştirilir. } \\
\text { Birinci aşamada; üç yıl için ortalama vergi } \\
\text { öncesi kar hesaplanır. } \\
\text { Ikinci aşamada; üç yıl için ortalama maddi } \\
\text { varlık hesaplanır. } \\
\text { Üçüncü aşamada; işletmelerin maddi varlık } \\
\text { karlılığı hesaplanır. } \\
\text { Dördüncü aşamada; sektörün maddi varlık } \\
\text { karlıı̆ı̆ı hesaplanır. } \\
\text { Beşinci aşamada; işletmelerin brüt ek } \\
\text { kazançları hesaplanır. } \\
\text { Altıncı aşamada; işletmelerin net ek } \\
\text { kazançları hesaplanır. } \\
\text { Yedinci aşamada; işletmelerin entelektüel } \\
\text { sermayeleri hesaplanır. }\end{array}$ \\
\hline $\begin{array}{l}\text { Üstün } \\
\text { yönleri }\end{array}$ & \multicolumn{2}{|c|}{$\begin{array}{l}\text {-Hesaplamada kullanılan verilerin kolay } \\
\text { elde edilebilir olması } \\
\text {-Basit şekilde hesaplanabilmesi }\end{array}$} & $\begin{array}{l}\text { - Basit şekilde } \\
\text { hesaplanabilmesi }\end{array}$ & $\begin{array}{l}\text { - Denetlenmiş finansal tablo verilerine } \\
\text { dayanması } \\
\text {-Hesaplamada kullanılan verilerin kolay } \\
\text { elde edilebilir olması } \\
\text {-Daha gerçekçi ve karşılaştırılabilir sonuçlar } \\
\text { vermesi }\end{array}$ \\
\hline Zayıf yönleri & \multicolumn{2}{|c|}{$\begin{array}{l}\text {-işletmenin piyasa değerini etkileyen } \\
\text { faktörlerin çok çeşitli olması } \\
\text {-Seçilen muhasebe politikalarının } \\
\text { defter değerini etkilemesi } \\
\text { - Sadece hisse senetleri borsada işlem } \\
\text { gören işletmelere uygulanabilmesi }\end{array}$} & $\begin{array}{l}\text {-iş̧letmenin piyasa } \\
\text { değerini etkileyen } \\
\text { faktörlerin çok } \\
\text { çeşitli olması }\end{array}$ & -Karmaşık ve zaman alıcı olması \\
\hline
\end{tabular}

Kaynak: Stewart, 1997; Çıkrıkcı ve Daştan, 2002: 24-26; Arıkboğa, 2003: 117-123; Acar ve Dalğar, 2005: 34-36; Erkal, 2006: 101-106; Karacan, 2007: 44-54. 
Entelektüel sermayeyi işletme düzeyinde ölçen yöntemlerin birbirine karşı bazı üstünlük ve zayıflıkları olsa da, bu yöntemler genel olarak işletmelerin maddi olmayan varlıklar sayesinde elde ettikleri gücü ortaya çıkarmaya ve işletmeler arasında karşılaştırma yapmaya imkan sağladıkları için önemlidir.

\section{Entelektüel Sermayenin Raporlanması}

Entelektüel sermayeyi raporlama ihtiyacının en temel sebebi, işletme içinde ve dışında yer alan bilgi kullanıcılarının işletmelerin maddi olarak görünmeyen değerleri hakkında bilgi sahibi olmak ve işletmelerin gerçek değerini bilmek istemeleridir (Yereli ve Gerşil, 2005: 28; Vaškelienè, 2007: 165). İşletmelerin defter değerleri ile piyasa değerleri arasındaki farkı açıklayabilmek için kullanılan şerefiye kavramının, sadece işletme birleşmelerinde veya işletmelerin satılması durumunda dikkate alınması sebebiyle yetersiz kaldığının anlaşılması, entelektüel sermaye değerinin ölçülmesi ve raporlanması ihtiyacını ortaya çıkarmıştır (Sarıay, 2016: 9). Entelektüel sermayenin raporlanmasını gerektiren diğer sebepler, finansal dilin oluşmasını sağlamak (Ünal, 2010: 32) ve Türkiye Muhasebe Standartları'nın öngördüğü gibi, finansal tablolarda gerçeğe uygun bilgi sunmaktır (Sarıay, 2016: 1).

Muhasebe açısından bakıldığında bilgi ürünü olan entelektüel sermaye bileşenlerinin finansal tablolara tam olarak yansıtılamaması, finansal tabloları yetersiz ve başarısız kılmaktadır (Kayalı, Yereli ve Ada, 2007: 68). Entelektüel sermaye ölçüm yöntemlerinin genel ihtiyacı karşılayacak düzeyde olmaması, denetiminin yapılamayacağının düşünülmesi, finansal muhasebe sistemi ve yasal düzenlemelerde yer alan bazı sınırlamalar, özellikle de maddi olmayan duran varlıklar ile ilgili olan standart olan TMS 38'in entelektüel sermayeyi açıklamakta yetersiz kalması ve entelektüel sermayenin finansal tablolarda raporlanmasına imkan vermemesi entelektüel sermaye ile ilgili bilgilerin finansal raporlama kapsamı dışında kalmasının sebepleridir (Bontis, 2001: 59; Vaškelienè, 2007: 165; Ünal, 2010: 36).

TMS 38'e göre bir kalemin maddi olmayan duran varlık olarak muhasebeleştirilmesi için, işletmenin "maddi olmayan duran varlık tanımı" ve "muhasebeleştirme kriterlerini" karşıladığını göstermesi gerekir (paragraf 18). Bu kapsamda, entelektüel sermayenin maddi olmayan duran varlık olarak muhasebeleştirilebilmesi için; geçmişteki bazı olayların sonucu olarak işletme tarafından kontrol edilebilmesi, işletmeye gelecekte ekonomik yarar sağlaması, varlıkla ilişkilendirilen beklenilen gelecekteki ekonomik yararın işletme için gerçekleşmesinin muhtemel olması ve varlığın maliyetinin güvenilir bir şekilde ölçülebilmesi gerekir. Bu açıdan değerlendirildiğinde entelektüel sermayenin muhasebeleştirilememesinin ve dolayısıyla finansal tablolarda raporlanamamasının iki temel sebebi vardır. Bunlar;

- Entelektüel sermaye bileşenleri "belirlenebilirlik, kontrol ve gelecekteki ekonomik yararın varlığı" şartlarını sağlamadığı için entelektüel sermayenin maddi olmayan varlık tanımına girmemesi,

- Genel kabul görmüş güvenilir bir ölçüm yöntemi olmadığı için maliyetinin güvenilir bir şekilde ölçülememesi sebebiyle muhasebeleştirme kriterlerini sağlamamasıdır.

Entelektüel sermayenin muhasebeye yansıtılması ve finansal tablolara aktarılmasıyla ilgili olarak ulusal ve uluslararası boyutta doğrudan yapılmış herhangi bir düzenlemenin bulunmaması önemli bir eksiklik olarak görülmektedir (Şamiloğlu ve Akgün, 2015: 486). İşletme literatüründe entelektüel semayenin raporlanmasına yönelik çeşitli çözüm önerilerinin tartışıldığı bilinmektedir. Geliştirilen öneriler arasında; geleneksel muhasebe sistemi ilkelerinin yeniden gözden geçirilebileceği, maddi olmayan duran varlıklar için özel bir muhasebe sistemi ya da ölçüm çerçevesi tasarlanabileceği (Vaškeliené, 2007: 165), ayrı bir standart olarak değerlendirilebileceği (Ünal, 2010: 36), "entelektüel sermaye faaliyet raporu" şeklinde finansal tablolardan ayrı olarak sunulabileceği (Özevren ve Yıldız, 2010: 286), işletmelerin finansal tablolarına ek olarak ya da finansal tabloların dipnotları kullanılarak açıklanabileceği (Yereli ve Gerşil, 2005: 28) yer almaktadır. Diğer bir bakış açısına göre, kısa vadede tek çözüm işletmeler tarafından entelektüel sermayenin gönüllü olarak açıklanmasıdır, uzun vadede ise bilgi kullanıcılarının entelektüel sermayeye ilişkin sunulan bilgilerin işletme performansını açıklamada faydalı olduğunu kabul etmeleri durumunda, işletmelerin bu açıklamayı yapmaya mecbur kalmasıdır (Bontis, 2001: 59). Vaškelienè'e göre en popüler yaklaşım, işletmeler tarafından entelektüel sermaye ile ilgili bilgilerin gönüllü olarak açıklanmasıdır (Vaškelienė, 2007: 165). 
Entelektüel sermayeyi raporlamaya yönelik geliştirilen tüm öneriler, entelektüel sermayenin sağlayacağı faydaların bilinmesinden kaynaklanmaktadır. Entelektüel sermayeyi raporlamanın işletmelere sağlayacağı faydalar; kredi kurumlarına teminat olarak gösterilerek borçlanma imkanı sağlaması, hisse senetlerinin piyasa performansını olumlu yönde etkilemesi, işletmenin satış fiyatını artırıcı bir etkide bulunması, rakipler karşısındaki durumun analiz edilerek üstün ve zayıf yönlerin belirlenmesinde ve zayıf yönlerin geliştirilmesinde katkı sağlaması, işletmenin rekabet gücünü artırması, yöneticilere gelecekle ilgili doğru kararlar almada yardımcı olması, çalışanların moral ve motivasyonunu artırması, entelektüel varlıkların daha etkin kullanılmasını sağlaması olarak sayılabilir (Kaya, 2008: 49; Acar ve Dalğar, 2005: 33). Bunun yanısıra işletme dışındaki bilgi kullanııılarına işletmelerin gerçek değeri hakkında bilgi vererek onların doğru kararlar almalarına yardımcı olması açııından da entelektüel sermayenin raporlanması büyük önem arzetmektedir.

\section{Literatür İncelemesi}

Literatürde entelektüel sermayenin ölçülmesine, muhasebeleştirilmesine ve raporlanmasına yönelik çeşitli teorik ve uygulamalı (ampirik) çalışmalar mevcuttur. Yapılan çalışmalarda yazarların entelektüel sermayeyi teorik olarak farklı şekillerde açıkladıkları, entelektüel sermaye değerlerini farklı yıllar, sektörler, işletmeler ve yöntemler bazında hesapladıkları, hesaplanan tutarları muhasebeleştirirken ve raporlarken çeşitli görüşler ortaya koydukları görülmektedir.

\subsection{Entelektüel Sermayenin Ölçülmesine Yönelik Yapılan Çalışmalar}

Literatürde entelektüel sermayenin ölçülmesini konu alan çalışmaların çoğunlukla entelektüel sermaye ölçüm yöntemlerinden "Entelektüel Katma Değer Katsayısı"nı kullanarak, entelektüel sermayenin işletme performansı üzerindeki etkisini araştırmaya odaklandığı görülmektedir. Bu çalışmaların daha çok finans ağılıklı olduğu ifade edilebilir. "Entelektüel Katma Değer Katsayısı" yönteminin kullanıldığı uygulamalı çalışmalara ilişkin özet bilgiler aşağıdaki Tablo 2'de sunulmaktadır.

Tablo 2'de yer alan bilgiler incelendiğinde, Entelektüel Katma Değer Katsayısı yöntemi ile elde edilen katsayılar ile işletme performans göstergeleri olarak kullanılan aktif karlılı̆ı, özsermaye karlılığı, aktif devir hızı, kaldıraç oranı, piyasa değeri/defter değeri arasındaki ilişkilerin analiz edildiği çalışmalardan farklı sonuçlar elde edildiği görülmektedir. Entelektüel sermaye ile finansal performans arasında güçlü ve pozitif yönlü ilişki bulan çalışmalar olduğu gibi, işletme performansını etkileyen temel unsurların fiziksel varlıklar olduğunu ve entelektüel sermayenin işletme performansı üzerinde etkili olmadığını tespit eden çalışmalar da vardır. Diğerlerinden farklı olarak, entelektüel sermayenin finansal kriz öncesi ve sonrasında küçük ve büyük ölçekli işletmelerin finansal performansı üzerindeki etkisi ve UMS/UFRS'lere geçişin entelektüel sermaye ve bileşenleri üzerindeki etkisi de araştırımıştır.

Literatürde entelektüel sermayeyi farklı yöntemler kullanarak ölçmeyi amaçlayan çok çeşitli çalışmalar yer almaktadır. Entelektüel sermayenin muhasebeleştirilmesinin ve raporlanmasının önemini vurgulayan çalışmaların, entelektüel sermayeyi işletme düzeyinde ölçen yöntemleri tercih ettikleri ifade edilebilir. Özellikle çalışmalarda entelektüel sermayeyi işletme düzeyinde ölçen yöntemler arasında yer alan "Hesaplanmış Maddi Olmayan Değer" yönteminin tercih edildiği görülmektedir. Bu kapsamda dikkat çeken çalışmalardan biri Uzay ve Savaş tarafından 2003 yılında, iso 500'de yer alan ve mobilya sektöründe faaliyet gösteren işletmeler (1999-2001) üzerinde yapılmıştır. Çalışmada "Hesaplanmış Maddi Olmayan Değer" yöntemi kullanılarak uygulama kapsamındaki işletmelerin entelektüel sermaye değerleri hesaplanmış ve bu değer ile işletmelerin defter değerleri ve net aktif toplamları arasındaki oransal ilişkiler incelenmiştir. Sonuç olarak işletmelerin entelektüel sermaye açısından güçlendirilmeleri gerektiği tespit edilmiştir. Diğer bir çalışma Bölükbaşı tarafından 2014 yılında Borsa İstanbul'da işlem gören sigorta işletmeleri (2009-2011) üzerinde gerçekleştirilmiştir. Çalışmada sigorta işletmelerinin entelektüel sermaye değerleri "Hesaplanmış Maddi Olmayan Değer" yöntemi kullanılarak tek tek hesaplanmış ve en yüksek entelektüel sermayeye sahip olan işletmenin Anadolu Hayat ve Emeklilik olduğu tespit edilmiştir. Entelektüel sermayeyi işletme düzeyinde ölçen yöntemlerin tamamını kullanarak Borsa İstanbul'da işlem gören yatırım ortaklıklarının (2010-2014) entelektüel sermayesini tespit etmeye yönelik karşılaştırmalı bir çalışma da Sarıay tarafından 2016 yılında yapılmıştır. Sonuç olarak "Hesaplanmış Maddi Olmayan Değer" yönteminde, sektöre ilişkin veriler 
kullanımasının bu yöntemi diğerlerinden ayıran en önemli özellik olduğu ve işletmelerin entelektüel sermaye değerlerinin en fazla bu yöntem sonucunda pozitif değer çıktığı belirlenmiştir.

Tablo 2. Entelektüel Katma Değer Katsayısı Yönteminin Kullanıldığı Çalışmalar

\begin{tabular}{|c|c|c|}
\hline Yazar (Yıl) & Çalışmanın Kapsamı & Çalışma Özeti \\
\hline $\begin{array}{l}\text { Purohit ve } \\
\text { Tandon } \\
\text { (2017) }\end{array}$ & $\begin{array}{l}\text { Hindistan'da faaliyet } \\
\text { gösteren halka açık } \\
\text { işletmeler (2004-2014) }\end{array}$ & $\begin{array}{l}\text { İşletmelerin entelektüel sermayeleri ölçülmüş ve entelektüel } \\
\text { sermayenin finansal performans üzerindeki etkisi araştırılmışır. } \\
\text { Entelektüel sermaye ile finansal performans arasında güçlü ve } \\
\text { pozitif yönlü bir ilişki saptanmıştır. }\end{array}$ \\
\hline $\begin{array}{l}\text { Kaupelytè } \\
\text { ve Kairytè } \\
(2016)\end{array}$ & $\begin{array}{l}\text { Avrupa'daki küçük ve } \\
\text { büyük ölçekli bankalar } \\
(2005-2014)\end{array}$ & $\begin{array}{l}\text { Bankaların entelektüel sermayesinin finansal performans } \\
\text { üzerindeki etkileri araştırılmıştır. Entelektüel sermayenin, finansal } \\
\text { kriz sonrasında büyük bankaların finansal performansı üzerinde, } \\
\text { finansal kriz öncesinde ise küçük bankaların performansı üzerinde } \\
\text { olumsuz etkileri olduğu tespit edilmiştir. }\end{array}$ \\
\hline $\begin{array}{l}\text { Dönmez ve } \\
\text { Erol (2016) }\end{array}$ & $\begin{array}{l}\text { BIST-Sürdürülebilirlik } \\
\text { endeksinde işlem gören } \\
\text { işletmeler (2014-2015) }\end{array}$ & $\begin{array}{l}\text { Entelektüel sermaye etkinlik katsayıları tespit edilerek, işletmelerin } \\
\text { performans göstergeleri ile ilişkisi analiz edilmiştir. İnsan sermayesi } \\
\text { etkinlik katsayısı ile özsermaye karlılığı arasında ve aktif karlıı̆ı ile } \\
\text { entelektüel sermaye etkinlik katsayısı arasında güçlü ve pozitif } \\
\text { yönlü ilişki bulunmuştur. }\end{array}$ \\
\hline $\begin{array}{l}\text { Singh ve } \\
\text { Narwal } \\
(2016)\end{array}$ & $\begin{array}{l}\text { Hindistan'da elektronik } \\
\text { endüstrisinde faaliyet } \\
\text { gösteren işletmeler } \\
\text { (2004-2014) }\end{array}$ & $\begin{array}{l}\text { Entelektüel sermaye ve bileşenleri ile finansal performans } \\
\text { arasındaki ilişki incelenmiştir. Insan sermayesinin finansal } \\
\text { performans üzerinde önemli katkısı olduğu ancak yapısal } \\
\text { sermayenin işletmenin finansal performansını iyileştirmede önemli } \\
\text { bir katkısı olmadığı saptanmıştır. Ayrıca fiziki sermayenin işletmenin } \\
\text { finansal performansını artırmadaki gücünün azaldığı belirlenmiştir. }\end{array}$ \\
\hline $\begin{array}{l}\text { Akpınar ve } \\
\text { Akpınar } \\
(2016)\end{array}$ & $\begin{array}{l}\text { Borsa İstanbul'da işlem } \\
\text { gören imalat işletmeleri } \\
(2010-2014)\end{array}$ & $\begin{array}{l}\text { Entelektüel sermaye bileşenlerinin işletme değeri ve performansı } \\
\text { üzerindeki etkisi analiz edilmiştir. Entelektüel sermaye ile işletme } \\
\text { değeri ve finansal performansı arasında pozitif bir ilişki } \\
\text { saptanmıştır. }\end{array}$ \\
\hline $\begin{array}{l}\text { Çalışkan } \\
\text { (2015) }\end{array}$ & $\begin{array}{l}\text { Borsa İstanbul'da işlem } \\
\text { gören bankalar (2013) }\end{array}$ & $\begin{array}{l}\text { Entelektüel sermayenin işletme performansı üzerindeki etkisi } \\
\text { incelenmiştir. Entelektüel sermaye etkinlik katsayılarının bankacılık } \\
\text { sektöründeki işletmelerin verimlilikleri, firma değerleri ve karlılıkları } \\
\text { üzerinde önemli etkilere sahip olduğu saptanmıştır. }\end{array}$ \\
\hline Şen (2014) & $\begin{array}{l}\text { Borsa İstanbul'da toprak } \\
\text { ve toprağa dayalı ürünler } \\
\text { sektöründe işlem gören } \\
\text { işletmeler }\end{array}$ & $\begin{array}{l}\text { UMS/UFRS'lere geçişin entelektüel sermaye ve bileşenleri } \\
\text { üzerindeki etkisi araştırılmıştır. Uygulama kapsamındaki } \\
\text { işletmelerin UMS/UFRS'lere geçişinin entelektüel katma değer } \\
\text { katsayısı üzerinde istatistiksel etkisi olmadığı tespit edilmiştir. }\end{array}$ \\
\hline $\begin{array}{l}\text { Yörük ve } \\
\text { Erdem } \\
(2008)\end{array}$ & $\begin{array}{lr}\text { IMKB'de işlem } & \text { gören } \\
\text { otomotiv sektörü } \\
\text { işletmeleri (2003) }\end{array}$ & $\begin{array}{l}\text { Entelektüel sermaye ve bileşenleri ile işletme performansı } \\
\text { arasındaki ilişki incelenmiştir. İ̧letme performansını etkileyen } \\
\text { temel unsurların fiziksel varlıklar olduğu sonucuna ulaşımıştır. }\end{array}$ \\
\hline $\begin{array}{l}\text { Kayalı, } \\
\text { Yereli ve } \\
\text { Ada (2007) }\end{array}$ & $\begin{array}{l}\text { IMKB'de } \\
\text { teknoloji } \\
(2005)\end{array}$ & $\begin{array}{l}\text { Entelektüel sermayenin firma değeri üzerindeki etkisi analiz } \\
\text { edilerek, işletmelerin entelektüel sermaye unsurlarına verdikleri } \\
\text { önem araştırılmıştır. Entelektüel sermayeye, bilgi yoğun sektörde } \\
\text { bile gereken önemin verilmediği sonucuna ulaşılmıştır. }\end{array}$ \\
\hline $\begin{array}{l}\text { Öztürk ve } \\
\text { Demirgüneş } \\
(2007)\end{array}$ & $\begin{array}{l}\text { IMKB'de işlem gören } \\
\text { üretim işletmeleri } \\
\text { 2002) }\end{array}$ & $\begin{array}{l}\text { Entelektüel sermayenin işletme performansı üzerindeki etkisi } \\
\text { incelenmiştir. Entelektüel sermayenin işletme performansı } \\
\text { üzerinde yeterince etkili bir unsur olmadığı tespit edilmiştir. }\end{array}$ \\
\hline $\begin{array}{l}\text { Şamiloğlu } \\
\text { (2006) }\end{array}$ & $\begin{array}{l}\text { IMKB'de işlem gören } \\
\text { bankalar (1998-2001) }\end{array}$ & $\begin{array}{l}\text { Entelektüel katma değer katsayısı yönteminin parametreleri ile } \\
\text { Piyasa Değeri/ Özkaynaklar Defter Değeri arasındaki ilişki } \\
\text { incelenmiş ve aralarında anlamlı bir ilişki olmadığı saptanmıştır. }\end{array}$ \\
\hline
\end{tabular}

\subsection{Entelektüel Sermayenin Muhasebeleştirilmesine ve Raporlanmasına Yönelik Yapılan Çalışmalar}

Entelektüel sermayenin muhasebeleştirilmesine ve finansal tablolarda sunulmasına yönelik yaklaşımlar sunan çalışmalara ait özet bilgiler şunlardır: 
Entelektüel Sermayeyi Hesaplanmış Maddi Olmayan Değer Yöntemi Ille Ölçme ve Raporlama

Tablo 3. Entelektüel Sermayenin Muhasebeleştirilmesini ve Finansal Tablolarda Sunulmasını Öneren Çalışmalar

\begin{tabular}{|c|c|c|c|}
\hline Yazar (yıl) & alışmanın Kapsamı & $\begin{array}{l}\text { Önerilen } \\
\text { Aktif Hesap }\end{array}$ & $\begin{array}{l}\text { Önerilen } \\
\text { Pasif Hesap } \\
\end{array}$ \\
\hline $\begin{array}{l}\text { Çıkrıkcı ve } \\
\text { Daştan } \\
(2002)\end{array}$ & $\begin{array}{l}\text { Entelektüel sermaye ve unsurları kavramsal olarak açıklanmış, } \\
\text { entelektüel } \quad \text { sermayenin ölçüm yöntemlerine, } \\
\text { muhasebeleştirilmesine, finansal durum tablosu ve gelir } \\
\text { tablosunda sunumuna ilişkin bilgiler verilmiştir. }\end{array}$ & $\begin{array}{l}265 \\
\text { Entelektüel } \\
\text { Varlıklar }\end{array}$ & $\begin{array}{l}502 \\
\text { Entelektüel } \\
\text { Sermaye }\end{array}$ \\
\hline $\begin{array}{l}\text { Alagöz ve } \\
\text { Özpeynirci } \\
(2007)\end{array}$ & $\begin{array}{l}\text { Entelektüel sermaye kavramı, unsurları, işletmeler açısından } \\
\text { entelektüel sermayenin önemi, muhasebeleştirilmesi ve finansal } \\
\text { durum tablosunda raporlanmasına yönelik bilgiler sunulmuştur. }\end{array}$ & $\begin{array}{r}2 \\
\text { Entel } \\
\text { Var }\end{array}$ & tüel \\
\hline & $\begin{array}{l}\text { Entelektüel sermaye kavramı, mali değerinin hesaplanması, } \\
\text { muhasebe bilgi sistemi içindeki yeri açıklanmış ve entelektüel } \\
\text { sermayenin muhasebeleştirilmesi ile finansal durum tablosu, gelir } \\
\text { tablosu ve entelektüel varlıklar tablosunda sunulmasına ilişkin } \\
\text { bilgiler verilmiştir. }\end{array}$ & $\begin{array}{l}265 \\
\text { Entelektüel } \\
\text { Varlıklar }\end{array}$ & $\begin{array}{l}504 \\
\text { Entelektüel } \\
\text { Sermaye }\end{array}$ \\
\hline $\begin{array}{l}\text { Kutlu } \\
\text { (2009) }\end{array}$ & $\begin{array}{l}\text { Entelektüel sermaye kavramı, unsurları ve ölçüm yöntemleri ile ilgili } \\
\text { genel açıklamalar yapılmış, "Hesaplanmış Maddi Olmayan Değer } \\
\text { Yöntemi” kullanılarak örnek bir işletmenin entelektüel sermayesi } \\
\text { hesaplanmış, entelektüel sermayenin muhasebeştirilmesine ve } \\
\text { finansal durum tablosunda raporlanmasına yönelik bilgiler } \\
\text { verilmiştir. }\end{array}$ & $\begin{array}{l}265 \\
\text { Entelektüel } \\
\text { Sermaye } \\
\text { Unsurları }\end{array}$ & $\begin{array}{l}510 \\
\text { Entelektüel } \\
\text { Sermaye }\end{array}$ \\
\hline $\begin{array}{l}\text { Zor ve } \\
\text { Bulut } \\
(2013)\end{array}$ & $\begin{array}{l}\text { Entelektüel sermayenin tanımı, unsurları, ölçülmesi, } \\
\text { muhasebeleştirilmesi ve finansal durum tablosu, gelir tablosu ve } \\
\text { entelektüel varlıklar tablosunda raporlanmasına yönelik } \\
\text { açıklamalar yapılmıştır. }\end{array}$ & $\begin{array}{l}265 \\
\text { Entelektüel } \\
\text { Varlıklar }\end{array}$ & $\begin{array}{l}502 \\
\text { Entelektüel } \\
\text { Sermaye }\end{array}$ \\
\hline $\begin{array}{l}\text { Sarıy } \\
(2016)\end{array}$ & $\begin{array}{l}\text { Borsa İstanbul'da işlem gören yatırım ortaklıklarının 2010-2014 } \\
\text { yıllarına ait Piyasa Değeri-Defter Değeri, Yaklaşık Tobin Q Değeri, } \\
\text { Hesaplanmış Maddi Olmayan Değer ve Ekonomik Katma Değer } \\
\text { yöntemleri kullanılarak entelektüel sermayeleri hesaplanmış, } \\
\text { muhasebeleştirilmiş ve finansal durum tablosunda raporlanmıştır. }\end{array}$ & $\begin{array}{l}2 . . \\
\text { Entelektüel } \\
\text { Sermaye } \\
\text { Varlıkları }\end{array}$ & $\begin{array}{l}5 . \\
\text { Entelektüel } \\
\text { Sermaye }\end{array}$ \\
\hline
\end{tabular}

Tablo 3'de yer alan bilgiler, entelektüel sermeyenin maddi olmayan duran varlık grubundan 265 nolu hesabın ve ödenmiş sermaye grubundan 502 veya 504 nolu hesaplardan birinin kullanılarak muhasebe kayıtlarına geçirilmesini öngörmektedir. Farklı bir görüş, entelektüel sermayenin ödenmiş sermaye grubunda izlenmemesi gerektiği, bunun yerine hesap planında boş bırakılan 51 nolu grubun kullanımının daha uygun olacağı kanaatindedir. Diğer bir görüşe göre, hesapların 2 ve 5 nolu hesap sınıflarında yer alması yeterlidir. Ayrıca yapılan çalışmalarda, entelektüel sermayenin sadece finansal durum tablosunda, hem finansal durum tablosu hem de gelir tablosunda, finansal durum tablosu ve gelir tablosuna ilave olarak entelektüel varlıklar tablosunda da sunulabileceği ileri sürülmüştür.

Entelektüel sermaye ile ilgili bilgilerin finansal tablolar dışında, işletmelerin faaliyet raporlarında açıklanması ve bilgi kullanıcılarına sunulması mümkündür. Literatürde yer alan çalışmaların bir kısmı da, işletmeler tarafından faaliyet raporlarında yer alan entelektüel sermayeye ilişkin bilgilerin açıklanma düzeyini, bu düzeyi etkileyen faktörleri, açıklamaların daha çok hangi entelektüel sermaye bileşeni ile ilgili olduğunu araştırmıştır. Yapılan çalışmalara ilişkin özet bilgiler şunlardır:

Arslan (2004), IMKB hisse senetleri piyasası endeksinde ilk 30 arasında yer alan işletmelerin 2003 yıına ait yıllık faaliyet raporlarını içerik analizi yöntemi ile incelediği çalışmada; işletmeler tarafından en fazla vurgulanan entelektüel sermaye bileşeninin insan sermayesi olmasına rağmen işletmelerin yıllık faaliyet raporlarında en fazla müşteri sermayesine ilişkin bildirimlerde bulunduklarını saptamıştır. İşletmelerin entelektüel sermaye kapsamı içerisinde en fazla üzerinde durdukları konu ise marka ve kurumsal imaj oluşumu olmuştur. 
Papula ve Volná (2012), Slovakya'da faaliyet gösteren ve 2010 yılında en iyi faaliyet raporu yarışmasına katılan 14 işletmenin faaliyet raporlarını içerik analizi yöntemiyle inceledikleri çalışma sonucunda; işletmelerin entelektüel sermaye raporlamasının öneminin farkında olmadıklarını tespit etmişlerdir. Slovak işletmeler tarafından entelektüel sermaye raporları oluşturulmadığı ancak işletmelerin yıllık faaliyet raporlarını bilgi kullanıcılarını entelektüel sermayenin bileşenleri hakkında bilgilendirmek amacıyla sıkıkla kullandıkları ortaya çıkmıştır. İşletmelerin insan sermayesi kapsamında en fazla işletme yönetimi ve çalışanlar; yapısal sermaye kapsamında finansal ilişkiler ve yönetim felsefesi, ilişkisel sermaye kapsamında ise sosyal sorumluluk ve marka ile ilgili bilgiler açıkladıkları tespit edilmiştir.

Beleneşi, Bogdan ve Popa (2016), yaptıkları çalışmada Romanya Bükreş Borsası'nda işlem gören 38 işletmenin 2010-2013 dönemlerine ait yıllık faaliyet raporlarında entelektüel sermayeye ilişkin bilgileri açıklama düzeylerini içerik analizi yöntemi ile incelemişlerdir. Elde edilen sonuçlar; işletmelerin entelektüel sermaye ile ilgili az miktarda açıklama yaptıklarını, en az açıklanan bilginin insan sermayesine, en çok açıklanan bilginin ise ilişkisel sermayeye ilişkin olduğunu ortaya koymuştur. Ayrıca işletmelerin entelektüel sermaye ile ilgili bilgi açıklama düzeylerinin zamanla artma eğilimi gösterdiği, ancak bu artışın yavaş olduğu tespit edilmiştir.

Popa, Beleneşi ve Rus (2016), Romanya Bükreş Borsası'nda işlem gören 38 işletmenin 2010-2013 dönemlerine ait yıllık faaliyet raporlarında yer alan bilgileri kullanarak, işletmelerin paydaş yapısının entelektüel sermaye ile ilgili bilgi açıklama düzeylerini etkileyip etkilemediğini araştırmışlardır. Çalışmada paydaş yapısı; devlet kurumları, yabancı yatırımcılar, kurumsal yarıtımcılar ve bireysel yatırımcılar olmak üzere dört gruba ayrımıştır. Çalışma sonuçlarına göre, paydaş yapısının entelektüel sermayeye yönelik bilgi açıklama düzeyini etkilediği, devlete ait işletmelerin entelektüel sermaye açıklama düzeylerinin, yabancı yatırımcıları olan işletmelere göre daha fazla olduğu, paydaşları çoğunlukla kurumsal yatırımcılar ve bireysel yatırımcılar olan işletmelerin entelektüel sermaye hakkında bilgi açıklamada örneklem ortalamasının altında kaldıkları saptanmıştır.

Madhani (2016), Hindistan borsasında işlem gören 36 işletmeyi entelektüel sermaye yoğun ve sermaye yoğun olmak üzere iki gruba ayırdığı çalışma sonucunda; entelektüel sermaye yoğun işletmeler ile sermaye yoğun işletmeler arasında kurumsal yönetim ve kamuyu aydınlatma uygulamaları açısından bir fark bulunmadığını saptamıştır.

Chan ve Lee (2017), entelektüel sermayeyi raporlamanın Hong Kong Borsası'nda işlem gören gayrimenkul geliştirme işletmelerinin piyasa değeri için önemli bir faktör olup olmadığını tespit etmek amacıyla yaptıkları çalışma sonucunda; uygulama kapsamındaki işletmelerin defter değerlerinin piyasa değerlerinden daha yüksek olduğu, işletmelerin piyasa değerleri ile entelektüel sermaye raporlamasının niceliği veya kalitesi arasında önemli derecede bir ilişki olmadığı ortaya çıkmıştır.

\section{Uygulama}

\subsection{Uygulamanın Amacı ve Kapsamı}

Çalışmanın amacı, entelektüel sermayeyi işletme düzeyinde ölçen yöntemlerden biri olan "Hesaplanmış Maddi Olmayan Değer Yöntemi" ni kullanarak uygulama kapsamındaki işletmelerin entelektüel sermaye değerlerini hesaplamak ve işletmelerin maddi olmayan varlıklardan yararlanma güçlerini ortaya koymaktır. Uygulamanın kapsamını 03.01.2018 tarihi itibariyle Borsa İstanbul'da Dokuma, Giyim Eşyası ve Deri sektöründe faaliyet gösteren toplam 24 işletme oluşturmaktadır.

\subsection{Uygulamanın Yöntemi}

İşletmelerin entelektüel sermaye değerlerinin ölçülmesinde, "Hesaplanmış Maddi Olmayan Değer Yöntemi" kullanılmıştır. Bu yöntemin seçilme sebepleri; işletmeleri bir bütün olarak değerlendirmeye imkan tanıması, entelektüel sermaye değerini diğer yöntemlere göre dış etkenlerden daha çok arındırarak hesaplaması, sektöre ilişkin veriler içermesi, finansal tablo verilerine dayandığı için uygulanabilirliğinin yüksek olması ve sonuçların karşılaştırılabilir olmasıdır. Yöntem yedi aşamadan oluşmaktadır. Yöntemin uygulanması 
için gereken veriler işletmelerin 2014, 2015 ve 2016 yıllarına ilişkin düzenledikleri finansal durum tablolarından ve gelir tablolarından elde edilmiştir. Bu verilere işletmelerin web sayfalarından ve Kamuyu Aydınlatma Platformu (KAP) sayfasından ulaşılmıştır. Uygulamada yıllık veriler kullanıımıştır.

\section{3. İ̧letmelerin Entelektüel Sermaye Değerlerinin Hesaplanması}

İşletmelerin entelektüel sermaye değerlerine ulaşabilmek için sırasıyla yedi aşamanın uygulanması gerekmektedir. Her bir aşamada yapılması gereken hesaplamalar aşağıdaki gibidir:

Birinci aşamada işletmelerin 2014, 2015 ve 2016 yıllarına ait ortalama vergi öncesi karları hesaplanır. Aşağıdaki Tablo 4'de işletmelerin üç yıla ait sürdürülen faaliyetler vergi öncesi karları ve bu üç yıl için hesaplanan ortalama vergi öncesi kar/zarar tutarları yer almaktadır:

Tablo 4. Ortalama Vergi Öncesi Kar/Zarar Tutarlarının Hesaplanması (TL)

\begin{tabular}{|c|l|r|r|r|r|}
\hline Sıra No & İşletmeler & $\mathbf{3 1 . 1 2 . 2 0 1 4}$ & $\mathbf{3 1 . 1 2 . 2 0 1 5}$ & $\mathbf{3 1 . 1 2 . 2 0 1 6}$ & Ortalama VÖK/Z Tutarları \\
\hline 1 & Akın Tekstil & 96.092 .597 & 80.875 .237 & 6.139 .489 & 61.035 .774 \\
\hline 2 & Arsan Tekstil & 43.791 .118 & 15.501 .919 & 11.563 .893 & 23.618 .977 \\
\hline 3 & Bilici Yatırım & 15.693 .336 & 22.393 .722 & 4.308 .551 & 14.131 .870 \\
\hline 4 & Birko & -6.283 .549 & -14.909 .040 & -16.331 .511 & -12.508 .033 \\
\hline 5 & Birlik Mensucat & -2.375 .106 & -6.548 .754 & -8.893 .267 & -5.939 .042 \\
\hline 6 & Bisaş Tekstil & -2.355 .156 & -4.824 .456 & 1.160 .472 & -2.006 .380 \\
\hline 7 & Bossa & 13.192 .269 & 25.345 .250 & -9.706 .769 & 9.610 .250 \\
\hline 8 & Dagi & 15.743 .088 & 5.464 .903 & -2.753 .409 & 6.151 .527 \\
\hline 9 & Derimod & 3.320 .380 & 6.585 .449 & 4.316 .734 & 4.740 .854 \\
\hline 10 & Desa & 5.206 .006 & -4.633 .426 & -13.530 .954 & -4.319 .458 \\
\hline 11 & Diriteks & -1.581 .695 & -3.570 .993 & -5.315 .775 & -3.489 .488 \\
\hline 12 & Esem & -6.188 .884 & 127.720 & -1.855 .526 & -2.638 .897 \\
\hline 13 & Hateks & 4.778 .047 & 2.798 .261 & 13.751 .409 & 7.109 .239 \\
\hline 14 & Karsu & -14.193 .644 & -11.102 .964 & -10.662 .706 & -11.986 .438 \\
\hline 15 & Kordsa & 99.550 .999 & 140.645 .220 & 223.894 .443 & 154.696 .887 \\
\hline 16 & Lüks Kadife & 4.361 .811 & 2.578 .910 & 18.916 .112 & 8.618 .944 \\
\hline 17 & Menderes & 31.253 .685 & -40.175 .180 & -5.885 .479 & -4.935 .658 \\
\hline 18 & Mish & -8.685 .920 & -24.445 .079 & -4.344 .031 & -12.491 .677 \\
\hline 19 & Rodrigo & -730.679 & 37.779 & 258.315 & -144.862 \\
\hline 20 & Royal & 30.449 .734 & 16.251 .462 & 10.045 .866 & 18.915 .687 \\
\hline 21 & Söktaş & 9.765 .593 & -18.756 .418 & -27.925 .333 & -12.305 .386 \\
\hline 22 & Sönmez & 7.953 .242 & 15.154 .309 & 15.887 .363 & 12.998 .305 \\
\hline 23 & Yataş & 10.554 .150 & 11.536 .190 & 22.446 .593 & 14.845 .644 \\
\hline 24 & Yünsa & 34.850 .102 & 5.219 .826 & -43.489 .951 & -1.140 .008 \\
\hline & & & Sektörün Ortalama $0 \ddot{K}$ Tutarı & $\mathbf{1 0 . 9 4 0 . 3 6 0}$ \\
\hline
\end{tabular}

Dokuma, Giyim Eşyası ve Deri sektöründe faaliyet gösteren işletmelerin ortalama vergi öncesi kar veya zarar tutarlarının hesaplandığı Tablo 4'de yer alan verilere göre, en yüksek ortalama kara sahip olan işletme açık farkla Kordsa'dır. Derimod ise en düşük ortalama kara sahip işletmedir. Toplam yedi işletmenin ortalama vergi öncesi karı, sektörün ortalama karından daha yüksektir. Sektörde faaliyet gösteren işletmelerin 12'si ortalama kar etmişken, kalan 12'si ortalama zarar etmiştir. Üç yılın ortalama en fazla zarar eden işletmesi Birko'dur.

İkinci aşamada işletmelerin dönemsonu finansal durum tablolarında yer alan 2014, 2015 ve 2016 yıllarına ait maddi varlık tutarlarının üç yıl için ortalaması hesaplanır. Ortalama maddi varlık tutarlarına ilişkin rakamsal veriler Tablo 5'de sunulmaktadır: 
S. Y. Pazarceviren - H. P. Kaya

Tablo 5. Ortalama Maddi Varlık Tutarlarının Hesaplanması (TL)

\begin{tabular}{|r|l|r|r|r|r|}
\hline Sıra No & İşletmeler & $\mathbf{3 1 . 1 2 . 2 0 1 4}$ & $\mathbf{3 1 . 1 2 . 2 0 1 5}$ & $\mathbf{3 1 . 1 2 . 2 0 1 6}$ & $\begin{array}{r}\text { Ortalama Maddi } \\
\text { Varlık Tutarları }\end{array}$ \\
\hline 1 & Akın Tekstil & 102.922 .307 & 98.264 .844 & 139.040 .268 & 113.409 .140 \\
\hline 2 & Arsan Tekstil & 60.539 .368 & 58.387 .337 & 61.890 .400 & 60.272 .368 \\
\hline 3 & Bilici Yatırım & 55.061 .050 & 61.942 .977 & 78.193 .303 & 65.065 .777 \\
\hline 4 & Birko & 120.558 .403 & 119.773 .349 & 110.032 .943 & 116.788 .232 \\
\hline 5 & Birlik Mensucat & 25.964 .890 & 64.509 .846 & 64.305 .803 & 51.593 .513 \\
\hline 6 & Bisaş Tekstil & 3.400 .241 & 1.413 .717 & 8.739 & 1.607 .566 \\
\hline 7 & Bossa & 209.352 .496 & 210.529 .372 & 168.123 .794 & 196.001 .887 \\
\hline 8 & Dagi & 16.382 .181 & 16.211 .478 & 67.294 .649 & 33.296 .103 \\
\hline 9 & Derimod & 14.212 .355 & 14.167 .960 & 16.587 .633 & 14.989 .316 \\
\hline 10 & Desa & 27.059 .779 & 25.950 .812 & 29.037 .330 & 27.349 .307 \\
\hline 11 & Diriteks & 13.309 .554 & 17.213 .036 & 16.870 .153 & 15.797 .581 \\
\hline 12 & Esem & 8.432 .541 & 4.168 .091 & 662.202 & 4.420 .945 \\
\hline 13 & Hateks & 53.266 .914 & 53.114 .471 & 195.100 .809 & 100.494 .065 \\
\hline 14 & Karsu & 99.646 .247 & 100.389 .081 & 100.452 .894 & 100.162 .741 \\
\hline 15 & Kordsa & 985.755 .026 & 1.045 .102 .304 & 1.215 .832 .426 & 1.082 .229 .919 \\
\hline 16 & Lüks Kadife & 7.817 .953 & 10.468 .463 & 31.971 .294 & 16.752 .570 \\
\hline 17 & Menderes & 155.713 .214 & 150.842 .077 & 271.610 .281 & 192.721 .857 \\
\hline 18 & Mish & 24.510 .390 & 22.665 .796 & 735.068 & 15.970 .418 \\
\hline 19 & Rodrigo & 1.461 .424 & 1.805 .517 & 2.276 .716 & 1.847 .886 \\
\hline 20 & Royal & 158.590 .498 & 153.636 .581 & 147.769 .000 & 153.332 .026 \\
\hline 21 & Söktaş & 237.234 .519 & 235.634 .686 & 341.216 .877 & 271.362 .027 \\
\hline 22 & Sönmez & 4.643 .051 & 3.736 .321 & 4.995 .158 & 4.458 .177 \\
\hline 23 & Yataş & 86.641 .280 & 97.148 .142 & 117.966 .332 & 100.585 .251 \\
\hline 24 & Yünsa & 53.324 .060 & 50.239 .535 & 50.563 .912 & 51.375 .836 \\
\hline & & \multicolumn{2}{|c|}{ Sektörün Ortalama Maddi Varlık Tutarı } & $\mathbf{1 1 6 . 3 2 8 . 5 2 1}$ \\
\hline
\end{tabular}

Tablo 5'de yer alan veriler, en yüksek ortalama maddi varlığa sahip olan işletmenin Kordsa olduğunu göstermektedir. Bu işletmeyi sırasıyla Söktaş ve Bossa takip etmektedir. Kordsa'nın, sektörün ortalama maddi varlık değerinden yaklaşık dokuz kat daha fazla maddi varlığa sahip olması dikkat çekicidir. Ortalama en düşük maddi varlığa sahip işletme ise Bisaş Tekstil'dir.

Üçüncü aşamada işletmelerin birinci aşamada bulunan ortalama vergi öncesi kar tutarları, ikinci aşamada bulunan ortalama maddi varlık tutarlarına bölünerek maddi varlıkların karlılığı hesaplanır. Birinci aşamada üç yılın ortalaması zarar hesaplanan işletmeler bu aşamada devre dışı bırakılmıştır. Bunların dışındaki işletmelerin maddi varlık karlıııklarına ilişkin rakamsal veriler Tablo 6'da yer almaktadır:

Tablo 6. İşletmelerin Maddi Varlık Karlılıklarının Hesaplanması

\begin{tabular}{|l|r|r|r|}
\hline İ̧letmeler & $\begin{array}{r}\text { Ortalama VÖK } \\
\text { Tutarları }\end{array}$ & $\begin{array}{r}\text { Ortalama Maddi } \\
\text { Varlık Tutarları }\end{array}$ & $\begin{array}{r}\text { Maddi Varlık } \\
\text { Karlılıkları }\end{array}$ \\
\hline Akın Tekstil & 61.035 .774 & 113.409 .140 & $\% 53,8$ \\
\hline Arsan Tekstil & 23.618 .977 & 60.272 .368 & $\% 39,2$ \\
\hline Bilici Yatırım & 14.131 .870 & 65.065 .777 & $\% 21,7$ \\
\hline Bossa & 9.610 .250 & 196.001 .887 & $\% 4,9$ \\
\hline Dagi & 6.151 .527 & 33.296 .103 & $\% 18,5$ \\
\hline Derimod & 4.740 .854 & 14.989 .316 & $\% 31,6$ \\
\hline Hateks & 7.109 .239 & 100.494 .065 & $\% 7,1$ \\
\hline Kordsa & 154.696 .887 & 1.082 .229 .919 & $\% 14,3$ \\
\hline Lüks Kadife & 8.618 .944 & 16.752 .570 & $\% 51,4$ \\
\hline Royal & 18.915 .687 & 153.332 .026 & $\% 12,3$ \\
\hline Sönmez Pamuklu & 12.998 .305 & 4.458 .177 & $\% 291,6$ \\
\hline Yataş & 14.845 .644 & 100.585 .251 & $\% 14,8$ \\
\hline
\end{tabular}


Tablo $6^{\prime}$ da maddi varlık karlılığına sahip işletmeler yer almaktadır. Birinci aşamada ortalama vergi öncesi kara sahip olmadığı tespit edilen işletmelerin maddi varlık karlılığı hesaplanamayacağı için, bu işletmeler tabloda yer almamıştır. Tablo 6'da yer alan bilgilere göre, maddi varlık karlılığı en yüksek olan işletme diğerlerine göre açık farkla Sönmez Pamuklu'dur. Bossa ise en düşük maddi varlık karlılığına sahip işletmedir.

İşletmelerin ikinci aşamada hesaplanan ortalama maddi varlık tutarları ile bu aşamada hesaplanan maddi varlık karlııkları arasında anlamlı bir ilişki olmadığı görülmektedir. Maddi varlık tutarı diğer işletmelerin çok üstünde olan Kordsa'nın maddi varlık karlılı̆ının \%14,3 hesaplanması, Kordsa'dan sonra en yüksek ikinci ortalama maddi varlığa sahip olan Söktaş’ın maddi varlıklarından kar elde edememesi ve üçüncü sırada yer alan Bossa'nın ise en düşük maddi varlık karlıı̆̆ına sahip işletme olması, maddi varlık tutarları ile maddi varlık karlıııları arasında anlamlı bir ilişki kurulamayacağını ortaya koymaktadır.

Dördüncü aşamada 2014, 2015 ve 2016 yıllarına ilişkin sektörün ortalama vergi öncesi kar tutarı, sektörün ortalama maddi varlık tutarına bölünerek, sektörün maddi varlık karlılı̆̆ hesaplanır. Yöntem gereği hesaplamaların devam edebilmesi için işletmelerin maddi varlık karlııklarının sektör karlılığından yüksek olması gerekmektedir. Karlıığı, sektör karlılı̆ının altında kalan işletmelerin entelektüel sermaye değerleri hesaplanamaz.

Tablo 7. Sektörün Maddi Varlık Karlılığının Hesaplanması

\begin{tabular}{|l|c|c|c|}
\hline Sektör & Ortalama VÖK & Ortalama Maddi Varlık & Maddi Varlık Karlılı̆ı \\
\hline Dokuma, Giyim Eşyası ve Deri & 10.940 .360 & 116.328 .521 & $\% 9,4$ \\
\hline
\end{tabular}

Tablo 7' de yer alan bilgiler doğrultusunda, sektörün \%9,4 olarak hesaplanan maddi varlık karlılığının altında kalan iki işletme yöntem gereği devre dışı bırakılmıştır. Bu işletmeler \%4,9 maddi varlık karlıı̆̆ına sahip Bossa ile \%7,1 maddi varlık karlılığına sahip Hateks'dir.

Beşinci aşamada öncelikle, sektörün maddi varlık karlılı̆ı ile işletmelerin ikinci aşamada hesaplanan ortalama maddi varlık tutarları çarpılarak normal kazanç tutarları bulunur. Daha sonra işletmelerin birinci aşamada hesaplanan ortalama vergi öncesi karlarından, normal kazanç tutarları çıkarılarak işletmelerin ortalama bir işletmeden ne kadar fazla kar ettiklerini gösteren değer bulunur. Bu değer ek kazanç veya getiri fazlası olarak adlandırılır. İşletmelerin elde ettikleri brüt ek kazançlara ilişkin hesaplamalar aşağıdaki Tablo 8 'de yer almaktadır:

Tablo 8. İşletmelerin Brüt Ek Kazanç Tutarlarının Hesaplanması (TL)

\begin{tabular}{|l|r|r|r|r|r|}
\hline İşletmeler & \multicolumn{1}{|c|}{$\begin{array}{c}\text { Ortalama } \\
\text { Maddi Varlık } \\
\text { Tutarları (1) }\end{array}$} & $\begin{array}{c}\text { Sektörün } \\
\text { Maddi Varlık } \\
\text { Karlılı̆ı (2) }\end{array}$ & $\begin{array}{c}\text { Normal Kazanç } \\
\text { Tutarları } \\
\mathbf{( 1 \times 2 ) ( 3 )}\end{array}$ & $\begin{array}{c}\text { Ortalama } \\
\text { VÖK Tutarları } \\
\text { (4) }\end{array}$ & $\begin{array}{c}\text { Brüt Ek Kazanç } \\
\text { Tutarları } \\
\text { (4-3) (5) }\end{array}$ \\
\hline Akın Tekstil & 113.409 .140 & \%9,4 & 10.660 .459 & 61.035 .774 & 50.375 .315 \\
\hline Arsan Tekstil & 60.272 .368 & $\% 9,4$ & 5.665 .603 & 23.618 .977 & 17.953 .374 \\
\hline Bilici Yatırım & 65.065 .777 & $\% 9,4$ & 6.116 .183 & 14.131 .870 & 8.015 .687 \\
\hline Dagi & 33.296 .103 & $\% 9,4$ & 3.129 .834 & 6.151 .527 & 3.021 .693 \\
\hline Derimod & 14.989 .316 & $\% 9,4$ & 1.408 .996 & 4.740 .854 & 3.331 .858 \\
\hline Kordsa & 1.082 .229 .919 & $\% 9,4$ & 101.729 .612 & 154.696 .887 & 52.967 .275 \\
\hline Lüks Kadife & 16.752 .570 & $\% 9,4$ & 1.574 .742 & 8.618 .944 & 7.044 .202 \\
\hline Royal & 153.332 .026 & $\% 9,4$ & 14.413 .210 & 18.915 .687 & 4.502 .477 \\
\hline Sönmez Pamuklu & 4.458 .177 & $\% 9,4$ & 419.069 & 12.998 .305 & 12.579 .236 \\
\hline Yataş & 100.585 .251 & $\% 9,4$ & 9.455 .014 & 14.845 .644 & 5.390 .630 \\
\hline
\end{tabular}

Tablo 8' de yer alan bilgiler, en yüksek brüt ek kazanca sahip olan işletmenin Kordsa, en düşük brüt ek kazanca sahip işletmenin ise Dagi olduğunu göstermektedir. 
Altıncı aşamada işletmelerin brüt ek kazanç tutarları üzerinden vergi hesaplanarak, net ek kazanç tutarları bulunur. Kurumlar vergisi ve gelir vergisi mevzuatında yer alan istisna ve muafiyetler nedeniyle uygulama kapsamındaki her bir işletmenin ayrı ayrı vergi yükünü hesaplamak mümkün olmamaktadır. Bu sebeple 2014, 2015 ve 2016 yılları için geçerli olan Kurumlar vergisi oranı dikkate alınmış ve ortalama vergi oranı \%20 kabul edilmiştir. Aşağıda yer alan Tablo 9'da öncelikle, işletmelerin beşinci aşamada hesaplanmış olan brüt ek kazanç tutarları üzerinden \%20 vergi kesintisi yapılarak ek kazancın vergisi bulunmuş, daha sonra brüt ek kazanç tutarından vergi çıkarılarak net ek kazanç tutarları hesaplanmıştır.

Tablo 9. İşletmelerin Net Ek Kazanç Tutarlarının Hesaplanması (TL)

\begin{tabular}{|l|c|c|r|r|}
\hline İşletmeler & $\begin{array}{c}\text { Brüt Ek Kazanç } \\
\text { Tutarları (1) }\end{array}$ & $\begin{array}{c}\text { Vergi Oranı } \\
\mathbf{( 2 )}\end{array}$ & $\begin{array}{c}\text { Ek Kazancın Vergi Tutarı } \\
\mathbf{( 1 \times 2 ) ( 3 )}\end{array}$ & $\begin{array}{c}\text { Net Ek Kazanç Tutarları } \\
\mathbf{( 1 - 3 ) ( 4 )}\end{array}$ \\
\hline Akın Tekstil & 50.375 .315 & $\% 20$ & 10.075 .063 & 40.300 .252 \\
\hline Arsan Tekstil & 17.953 .374 & $\% 20$ & 3.590 .675 & 14.362 .699 \\
\hline Bilici Yatırım & 8.015 .687 & $\% 20$ & 1.603 .137 & 6.412 .550 \\
\hline Dagi & 3.021 .693 & $\% 20$ & 604.339 & 2.417 .354 \\
\hline Derimod & 3.331 .858 & $\% 20$ & 666.372 & 2.665 .486 \\
\hline Kordsa & 52.967 .275 & $\% 20$ & 10.593 .455 & 42.373 .820 \\
\hline Lüks Kadife & 7.044 .202 & $\% 20$ & 1.408 .840 & 5.635 .362 \\
\hline Royal & 4.502 .477 & $\% 20$ & 900.495 & 3.601 .982 \\
\hline Sönmez Pamuklu & 12.579 .236 & $\% 20$ & 2.515 .847 & 10.063 .389 \\
\hline Yataş & 5.390 .630 & $\% 20$ & 1.078 .126 & 4.312 .504 \\
\hline
\end{tabular}

Her işletmeden aynı oranda vergi kesintisi yapıldığı için en yüksek brüt ek kazanca sahip olan Kordsa, aynı şekilde en yüksek net ek kazanca sahip işletme konumundadır. Bunu sırasıyla Akın Tekstil ve Arsan Tekstil izlemektedir. En düşük net ek kazanca sahip işletme ise Dagi'dir.

Yedinci aşamada bir önceki aşamada her bir işletme için hesaplanan net ek kazanç tutarları, işletmelerin ağırlıklı ortalama sermaye maliyetine (AOSM) bölünerek entelektüel sermaye değerleri hesaplanır.

Vergi oranı gibi ağırlıklı ortalama sermaye maliyeti de, işletmelere özgü sermaye yapısı, faiz oranı gibi koşullar tarafından belirlendiği için her bir işletmeye ait AOSM hesaplamak mümkün olmamaktadır. İstanbul Sanayi Odası tarafından Mayıs 2017'de yapılan bir çalışmada, tekstil ürünleri, giyim eşyaları ve deri ürünleri imalatı yapan işletmeler için hesaplanan AOSM'ler dikkate alındığında, (iSO, 2017: 31-39) uygulama kapsamındaki işletmelere ilişkin AOSM \%15 olarak kabul edilebilir.

Tablo 10. İşletmelerin Entelektüel Sermaye Değerlerinin Hesaplanması (TL)

\begin{tabular}{|l|r|r|r|}
\hline İşletmeler & $\begin{array}{c}\text { Net Ek Kazanç } \\
\text { Tutarları (1) }\end{array}$ & $\begin{array}{c}\text { AOSM } \\
\text { (2) }\end{array}$ & $\begin{array}{c}\text { Entelektüel Sermaye } \\
\text { Değerleri (1/2) (3) }\end{array}$ \\
\hline Akın Tekstil & 40.300 .252 & $\% 15$ & 268.668 .346 \\
\hline Arsan Tekstil & 14.362 .699 & $\% 15$ & 95.751 .326 \\
\hline Bilici Yatırım & 6.412 .550 & $\% 15$ & 42.750 .333 \\
\hline Dagi & 2.417 .354 & $\% 15$ & 16.115 .693 \\
\hline Derimod & 2.665 .486 & $\% 15$ & 17.769 .906 \\
\hline Kordsa & 42.373 .820 & $\% 15$ & 282.492 .133 \\
\hline Lüks Kadife & 5.635 .362 & $\% 15$ & 37.569 .080 \\
\hline Royal & 3.601 .982 & $\% 15$ & 24.013 .213 \\
\hline Sönmez Pamuklu & 10.063 .389 & $\% 15$ & 67.089 .260 \\
\hline Yataş & 4.312 .504 & $\% 15$ & 28.750 .026 \\
\hline
\end{tabular}

Tablo $10^{\prime}$ da yer alan bilgiler, en yüksek entelektüel sermayeye sahip olan işletmenin Kordsa olduğunu, bu işletmeyi sırasıyla Akın Tekstil ve Arsan Tekstil'in izlediğini göstermektedir. Dagi ise en düşük entelektüel sermayeye sahip işletmedir. 


\subsection{Bulguların Değerlendirilmesi}

Borsa İstanbul'da Dokuma, Giyim Eşyası ve Deri sektöründe 03.01.2018 tarihi itibariyle faaliyet gösteren toplam 24 işletmenin "Hesaplanmış Maddi Olmayan Değer" yöntemi kullanılarak 2014, 2015 ve 2016 yıllarına ait entelektüel sermaye değerlerinin hesaplanmaya çalışıldığı bu çalışma sonucunda, sadece 10 işletmenin entelektüel sermaye değeri hesaplanabilmiştir. Bunun sebebi 12 işletmenin maddi varlık karlılığına sahip olmaması, 2 işletmenin ise maddi varlık karlııı̆ının, sektörün maddi varlık karlığından daha düşük olmasıdır. Entelektüel sermaye, işletmelerin maddi varlıklarını kullanarak elde ettikleri kazancın üzerindeki ilave bir değeri ifade ettiği için, sektörün maddi varlık karlılığını aşamayan ve maddi varlıklarını kara dönüştürme potansiyeline sahip olmayan işletmelerin entelektüel sermaye değerinden bahsedilemez.

Entelektüel sermayesi hesaplanan 10 işletmeden, entelektüel sermayesini en etkin şekilde kullanarak kara dönüştürebilen ve sektördeki diğer işletmeler karşısında rekabet avantajı sağlayan işletme Kordsa olmuştur. Kordsa'yı sırasıyla Akın Tekstil ve Arsan Tekstil takip etmiştir. Bu üç işletme ile karşılaştırıldığında, sektördeki diğer işletmelerin entelektüel sermaye değerlerinin oldukça düşük seviyede olduğu ifade edilebilir. Çalışmada dikkat çeken bir diğer bulgu, entelektüel sermayesi hesaplanabilen işletmeler arasında en düşük ortalama maddi varlığa sahip olan Sönmez Pamuklu'nun aynı zamanda en yüksek maddi varlık karlılığına sahip işletme olmasıdır.

Bu çalışmadan elde edilen bulgular, çalışmanın yazarları tarafından 2008 yılında tamamlanmış olan yüksek lisans tezinde yer alan bulgularla karşılaştırılabilir. Tez çalışmasında iMKB'de Dokuma, Giyim Eşyası ve Deri sektöründe faaliyet gösteren işletmelerin 2005, 2006 ve 2007 yıllarına ait entelektüel sermaye değerleri "Hesaplanmış Maddi Olmayan Değer" yöntemi kullanılarak hesaplanmıştır. Her iki çalışmanın da anakütlesi ve yöntemi aynıdır. Çalışmalara ait özet bulgular aşağıda sunulmaktadır:

Tablo 11. Karşılaştırma

\begin{tabular}{|c|c|c|c|c|c|}
\hline \multicolumn{6}{|c|}{ 2005, 2006 ve 2007 Yıllarına Ait Veriler Kullanılarak Yapılan Hesaplamalar } \\
\hline İşletmeler & $\begin{array}{r}\text { Ortalama } \\
\text { vöK Tutarları }\end{array}$ & $\begin{array}{r}\text { Ortalama Maddi } \\
\text { Varlık Tutarları }\end{array}$ & $\begin{array}{r}\text { Maddi Varlık } \\
\text { Karlıııları }\end{array}$ & $\begin{array}{r}\text { Net Ek Kazanç } \\
\text { Tutarları }\end{array}$ & $\begin{array}{r}\text { Entelektüel } \\
\text { Sermaye Değeri }\end{array}$ \\
\hline Altınyıldız & 13.600 .475 & 90.040 .754 & $\% 15,1$ & 5.459 .062 & 27.295 .310 \\
\hline Bossa & 20.289 .106 & 229.296 .261 & $\% 8,9$ & 5.294 .576 & 26.472 .880 \\
\hline Ceylan Giyim & 870.789 & 4.045 .059 & $\% 21,5$ & 401.122 & 2.005 .610 \\
\hline Derimod & 3.021.590 & 2.829 .050 & $\% 106,8$ & 1.728 .083 & 8.640 .415 \\
\hline Desa & 5.981 .972 & 8.164 .785 & $\% 73,3$ & 3.344 .240 & 16.721 .200 \\
\hline Kordsa & 63.710 .248 & 619.551 .621 & $\% 10,3$ & 19.639 .600 & 98.198 .000 \\
\hline Menderes & 10.351 .190 & 106.274 .315 & $\% 9,7$ & 3.022 .484 & 15.112 .420 \\
\hline Söktaş & 5.380 .048 & 106.326 .414 & $\% 5,1$ & 38.236 & 191.180 \\
\hline Vakko & 24.598 .143 & 16.703 .005 & $\% 147,3$ & 14.257 .796 & 71.288 .980 \\
\hline Yataş & 3.210 .872 & 43.334.771 & $\% 7,4$ & 626.480 & 3.132 .400 \\
\hline Yünsa & 9.233 .130 & 51.697 .983 & $\% 17,9$ & 3.988 .939 & 19.944 .695 \\
\hline \multicolumn{6}{|c|}{$\begin{array}{l}\text { Sektörün Ortalama Maddi Varlık Karlıı̆ı \%5, Vergi Oranı \%40, Ağırlıklı Ortalama Sermaye Maliyeti ise \%20 alınarak } \\
\text { hesaplama yapıımıştır. }\end{array}$} \\
\hline \multicolumn{6}{|c|}{ 2014, 2015 ve 2016 Yıllarına Ait Veriler Kullanılarak Yapılan Hesaplamalar } \\
\hline İşletmeler & $\begin{array}{r}\text { Ortalama } \\
\text { vök Tutarları }\end{array}$ & $\begin{array}{l}\text { Ortalama Maddi } \\
\text { Varlık Tutarları }\end{array}$ & $\begin{array}{r}\text { Maddi Varlık } \\
\text { Karlııkları }\end{array}$ & $\begin{array}{r}\text { Net Ek Kazanç } \\
\text { Tutarları }\end{array}$ & $\begin{array}{r}\text { Entelektüel } \\
\text { Sermaye Değeri }\end{array}$ \\
\hline Akın Tekstil & 61.035 .774 & 113.409 .140 & $\% 53,8$ & 40.300 .252 & 268.668 .346 \\
\hline Arsan Tekstil & 23.618 .977 & 60.272 .368 & $\% 39,2$ & 14.362 .699 & 95.751 .326 \\
\hline Bilici Yatırım & 14.131 .870 & 65.065 .777 & $\% 21,7$ & 6.412 .550 & 42.750 .333 \\
\hline Dagi & 6.151 .527 & 33.296 .103 & $\% 18,5$ & 2.417 .354 & 16.115 .693 \\
\hline Derimod & 4.740 .854 & 14.989 .316 & $\% 31,6$ & 2.665 .486 & 17.769 .906 \\
\hline Kordsa & 154.696 .887 & 1.082.229.919 & $\% 14,3$ & 42.373 .820 & 282.492 .133 \\
\hline Lüks Kadife & 8.618 .944 & 16.752 .570 & $\% 51,4$ & 5.635 .362 & 37.569 .080 \\
\hline Royal & 18.915 .687 & 153.332 .026 & $\% 12,3$ & 3.601 .982 & 24.013 .213 \\
\hline Sönmez Pamuklu & 12.998 .305 & 4.458 .177 & $\% 291,6$ & 10.063 .389 & 67.089 .260 \\
\hline Yataş & 14.845 .644 & 100.585 .251 & \%14,8 & 4.312 .504 & 28.750 .026 \\
\hline
\end{tabular}


Aynı sektörde faaliyet gösteren işletmelerin farklı yıllara ait verileri kullanılarak aynı yöntemle hesaplanan entelektüel sermaye değerleri incelendiğinde, öncelikle yapılan hesaplamalarda esas alınan bazı verilerin farkııı̆̆ı dikkat çekmektedir. Çalışmalarda kullanılan sektörün ortalama maddi varlık karlııı̆ının, vergi oranının, ağırlıklı ortalama sermaye maliyetinin ve sektörde faaliyet gösteren işletmelerin zamana ve şartlara bağlı olarak farklılık göstermesi doğaldır.

Sonuçlar genel olarak karşılaştırıldığında, her iki çalışmada da en yüksek entelektüel sermayeye sahip olan işletme Kordsa'dır. Kordsa'nın entelektüel sermaye değerini yaklaşık 1,9 kat (\%187) artırdığı ifade edilebilir. Sektörde varlığını sürdüren ve entelektüel sermaye değerini zamanla artıran diğer işletmeler Derimod ve Yataş'tır. Entelektüel sermaye artışı Derimod'un yaklaşık 1 kat (\%105), Yataş'ın ise 8,2 kat (\%817) olarak gerçekleşmiştir. Desa, Söktaş ve Yünsa 2005, 2006 ve 2007 yıllarına ait veriler kullanılarak yapılan hesaplamalara göre entelektüel sermaye değerine sahipken, bu çalışmada entelektüel sermayesi hesaplanamayan işletmeler arasında yer almaktadır. Bunun sebebi söz konusu işletmelerin 2014, 2015 ve 2016 yıllarında ait ortalama vergi öncesi kara sahip olmamaları, diğer bir ifade ile daha önceden sahip oldukları entelektüel sermaye değerini son yıllarda kara dönüştürmeyi başaramamalarıdır.

\section{Sonuç}

Entelektüel sermaye, günümüz işletmelerinin sahip olmak ve en etkin şekilde kullanmak istedikleri bilgi temelli tüm değerleri kapsayan bir kavramdır. Bu sebeple entelektüel sermayenin insan sermayesi, yapısal sermaye ve ilişkisel sermaye bileşenlerini ortaya çıkarmak, geliştirmek ve işletme yararına kullanarak, kara dönüştürmek işletmelerin temel amacı haline gemiştir.

Piyasada faaliyet gösteren her işletmenin belirli bir entelektüel sermayesi vardır, önemli olan bu sermayeyi değere dönüştürmek ve işletmeye katkı sağlar hale getirebilmektir. Yapılan bu çalışmada, Borsa İstanbul'da Dokuma, Giyim Eşyası ve Deri sektöründe işlem gören işletmelerin 2014, 2015 ve 2016 yıllarına ilişkin entelektüel sermaye değeri "Hesaplanmış Maddi Olmayan Değer Yöntemi" kullanılarak hesaplanmaya çalışılımıştır. Uygulama kapsamındaki işletmeler arasından entelektüel sermaye değeri hesaplanabilen işletme sayısı 10'dur. Bunların dışındaki işletmelerin, varolan entelektüel sermayelerini etkin kullanamamaları sebebiyle, entelektüel sermaye değerleri hesaplanamamıştır.

Elde edilen bulgulara göre, Kordsa entelektüel sermaye bileşenlerine yaptığı yatırımı kara dönüştürme başarısı en yüksek olan işletmedir. Akın Tekstil ikinci sırada olmasına rağmen Kordsa'yı çok az bir farkla takip etmektedir. Bu iki işletmenin entelektüel sermayeyi en verimli şekilde kullandığı ve vergi öncesi kar açısından sektörde lider konumda olduğu bir gerçektir. Bu sonuç ise entelektüel sermayenin, işletmelerin karlıığı üzerindeki olumlu etkisini göstermektedir.

Iş̧letmeler açısından bir değer olduğu kabul edilen entelektüel sermayenin ölçülmesine ve raporlanmasına yönelik literatürde çeşitli çalışmalar yer almaktadır. Öncelikle entelektüel sermayeyi ölçme yöntemleri değerlendirilecek olursa, hem işletme düzeyinde hem de bileşenlerine ayırarak entelektüel sermayeyi ölçen çeşitli yöntemler geliştirilmiştir. Bu yöntemlerin birbirine karşı üstünlük ve zayıflıklarının olması, entelektüel sermayenin ölçülememesi anlamına gelmez. Mevcut muhasebe sisteminde kullanılan ölçüm yöntemleri için de aynı durum söz konusudur. Burada önemli olan entelektüel sermayenin finansal tablolarda sunulması ise, ölçüm yönteminin entelektüel sermayeyi parasal tutar olarak hesaplaması ve güvenilir olması esastır. Bu çalışmada uygulanan "Hesaplanmış Maddi Olmayan Değer" yönteminin entelektüel sermaye değeri hesaplanmasında kullanılabilecek güvenilir bir yöntem olduğu düşünülmektedir. Yöntem, hesaplamada kullanılan verilerin finansal tablolara dayanması, işletmenin bir bütün olarak entelektüel sermaye değerini hesaplamaya yönelik olması, sektöre ait veri içermesi, hem işletme bazında hem de sektör bazında karşılaştırma yapmaya imkan tanıması gibi özellikler açısından olumlu değerlendirilebilir. Yöntemin en büyük kısıtları, işletmelerin her biri için ayrı ayrı vergi yükü ve ağırıklı ortalama sermaye maliyetinin hesaplanmasının güç olmasıdır.

TMS 38 gereği, entelektüel sermayenin muhasebeleştirilmesi için güvenilir bir şekilde ölçülmesinin yanısıra maddi olmayan varlık tanımı şartlarını da sağlaması gerekmektedir. Entelektüel sermaye bileşenleri "belirlenebilirlik, kontrol ve gelecekteki ekonomik yararın varlığı" şartlarını sağlamadığı için entelektüel 
sermaye, maddi olmayan varlık tanımına girmemektedir. Dolayısıyla mevcut muhasebe standartları entelektüel sermayenin muhasebeleştirilmesine ve finansal tablolarda yer almasına izin vermemektedir. Bu sebeple entelektüel sermayeyi 26 nolu hesap grubunda maddi olmayan varlık olarak kaydetmeye yönelik geliştirilen önerilerin mevcut şartlarda geçerli olmadığı ifade edilebilir. Muhasebe standartlarında yapılacak yeni bir düzenleme ile entelektüel sermayenin muhasebeleştirilmesi mümkün hale geldiği taktirde, 26 nolu hesap grubunun kullanımı uygun olacaktır.

Genel olarak değerlendirildiğinde, entelektüel sermayenin finansal tablolarda sunulmasına yönelik düzenlemeler yapılmasının yararlı olacağı düşünülmektedir. Mevcut şartlarda ise, TMS 38 entelektüel sermayeyi maddi olmayan duran varlık olarak kabul etmediği için, entelektüel sermayeye ilişkin bilgilerin işletmelerin yıllık faaliyet raporlarında sunulması en doğru raporlama yaklaşımı olarak değerlendirilmektedir. İ̧letmelerin gerçek değeri, bilgi kullanııılarına açık ve anlaşıır bir şekilde yıllık faaliyet raporları kullanılarak anlatılabilir. Entelektüel sermaye bileşenlerine ait sınırlı bilgiler içerdiği bilinen faaliyet raporları, entelektüel sermaye değerine ilişkin hesaplama, analiz ve değerlendirme içerecek şekilde genişletilebilir. Bu da gönüllülük esasına dayalı olarak değil de, Gümrük ve Ticaret Bakanlığı tarafından yayınlanan "Şirketlerin Yıllık Faaliyet Raporunun Asgari İçeriğinin Belirlenmesi Hakkında Yönetmelik"de değişiklik yapılarak zorunlu sağlanmalıdır. Böylece işletmelerin finansal tablolarda görünen defter değeri ile piyasa değeri arasındaki fark, bilgi kullanıcılarına yıllık faaliyet raporları aracııı̆ıyla daha iyi açıklanabilir.

\section{Kaynaklar}

Acar, D., \& Dalğar, H. (2005). Entelektüel sermayenin ölçülmesinde muhasebe bilgi sisteminin katkısı. Muhasebe ve Denetime Bakış Dergisi, 14, 23-40.

Akpınar, O., \& Akpınar, A. T. (2016). Entellektüel sermaye bileşenlerinin işletme değerine ve performansına etkisi: Türkiye'deki imalat işletmeleri örneği. Kastamonu Üniversitesi Iktisadi ve Idari Bilimler Fakültesi Dergisi, 12, 142153.

Alagöz, A., \& Özpeynirci, R. (2007). Bilgi toplumunda entelektüel varlıklar ve raporlanması. Afyon Kocatepe Üniversitesi, i.i.B.F. Dergisi, 9(2), 167-18.

Arıkboğa, F. Ş. (2003). Entellektüel sermaye. İstanbul: Derin Yayınları.

Arslan, Ö. (2004). Entelektüel sermayenin Türkiye'deki raporlanma şeklinin incelenmesi. Dokuz Eylül Üniversitesi Işletme Fakültesi Dergisi, 5(2), 78-87.

Aşıkoğlu, R., \& Aşıkoğlu, M. (1998). Bilgi toplumuna geçiş sürecinde entellektüel sermayenin işletmenin piyasa degerine etkisi. Anadolu Üniversitesi Iktisadi ve Idari Bilimler Fakültesi Dergisi, 14(1-2), 585.

Bayazıtlı, E. (2000). Entelektüel sermaye gelecek binyııın katma değer başarısında anahtar. Muhasebe ve Denetime Bakış Dergisi, 121.

Beleneşi, M., Bogdan, V., \& Popa, D. N. (2016). Research regarding the disclosure behaviour of intellectual capital of listed Romanian entities. Annals of the University of Oradea, Economic Science Series, 25(2), 427-436.

Bilmedik, F. (2013). Entellektüel sermaye. http://danismend.com/kategori/altkategori/entellektuel-sermaye/ (Erişim Tarihi, 13 Ocak 2018).

Bontis, N. (2001). Assessing knowledge assets: A review of the models used to measure intellectual capital. International Journal of Management Reviews, 3(1), 45,59.

Bölükbaşı, Y. (2014). Entelektüel sermayenin işletme bazında ölçülmesinde kullanılan yöntemler ve sigorta sektöründe bir araştırma. Marmara Üniversitesi i.i.B.F. Dergisi, 36(1), 425-447.

Chan, E. C. W., \& Lee, R. W. B. (2017). Intellectual capital reporting: A study of Hong Kong listed property development companies. Proceedings of the 14th International Conference on Intellectual Capital, Knowledge Management \& Organisational Learning, China, 397-405.

Çalışan, M. M. T. (2015). Bilgi ekonomisinde entelektüel sermaye: Borsa isstanbul'da bankacılık sektörü uygulaması. Yönetim ve Ekonomi Araştırmaları Dergisi, 13(3), 121-137.

Çıkrıkcı, M., \& Daştan, A. (2002). Entelektüel sermayenin temel finansal tablolar aracılığıyla sunulması. Bankacılar Dergisi, 43, 18-32. 
Dönmez, A., \& Erol, İ. (2016). Entelektüel sermayenin ölçülmesi: VAIC ${ }^{\text {TM }}$ yöntemi yardımıyla BIST-Sürdürülebilirlik endeksi işletmeleri üzerine bir uygulama. Mali Çözüm Dergisi, 138, 27-56.

Eren, E., \& Akpınar, S. (2004). Yapısal sermayenin işletme performansı üzerindeki etkilerinin araştırılması. Öneri Dergisi, 6(22), 9-17.

Erkal, Z. E. (2006). Entelektüel sermaye ölçülmesi ve raporlanması. İstanbul: Derin Yayınları.

Hobikoğlu, E. H. (2011). Entelektüel sermayenin önemi, sınıflandırılması ve ölçme yöntemleri: Kuramsal bir çerçeve. Sosyal Bilimler Dergisi, 1, 86-99.

İstanbul Sanayi Odası (iSO). (2017). 1000 büyük sanayi kuruluşunun sermaye maliyeti analizi tematik raporlar-II, 31-39.

Karacan, S. (2007). Entelektüel sermayenin muhasebeleştirilmesi ve finansal tablolarda sunulması. Ankara: Orient Yayınları.

Kaupelytè, D., \& Kairytė, D. (2016). Intellectual capital efficiency impact on european small and large listed banks financial performance. International Journal of Management, Accounting and Economics, 3(6), 367-377.

Kaya, H. P. (2008). Entelektüel sermayenin finansal tablolar aracılığıla sunulması sorunu ve çözüm önerileri. Sakarya Üniversitesi Sosyal Bilimler Enstitüsü, Yüksek Lisans Tezi, Sakarya..

Kayalı, C. A., Yereli, A. N., \& Ada, Ş. (2007). Entelektüel katma değer katsayısı yöntemi kullanılarak entelektüel sermayenin firma değeri üzerindeki etkisinin belirlenmesine yönelik bir araştırma. Celal Bayar Üniversitesi iktisadi ve Idari Bilimler Fakültesi Yönetim ve Ekonomi Dergisi, 14(1), 67-90.

Kutlu, H. A. (2009). Entelektüel sermaye: Türkiye muhasebe sisteminde raporlanabilir mi? Hacettepe Üniversitesi Iktisadi ve Idari Bilimler Fakültesi Dergisi, 27(1), 235-257.

Madhani, P. M. (2016). Intellectual capital (IC) intensity vs. capital intensity: Impact on corporate governance and disclosure practices of firms. SCMS Journal of Indian Management, 13(4), 62-82.

Özevren, M., \& Yıldız, S. (2010). Entelektüel sermayenin ölçüm yöntemleri ve kriterlerinin belirlenmesi üzerine bir araştırma. Marmara Üniversitesi i.i.B.F. Dergisi, 14(2), 286.

Öztürk, M. B., \& Demirgüneş, K. (2007). Entellektüel sermayenin firma değeri üzerindeki etkisinin entellektüel katma değer katsayısı yöntemi ile tespiti: Hisse senetleri iMKB'de işlem gören üretim firmaları üzerine ampirik bir çalışma. IMKB Dergisi, 10(37), 59-80.

Pereira-Rodrigues, G. \& Santos-Rodrigues, H. (2017, April). Intellectual Capital Measurements- Its Application in Practice: Literature Review. Proceedings of the 9th European Conference on Intellectual Capital, Lisbon/Portugal, 351-352.

Popa, D. N., Beleneşi, M., \& Rus, L. (2016). The correlation between the intellectual capital disclosure level and the stakeholder structure. Annals of the University of Oradea, Economic Science Series, 25(2), 444-453.

Papula, J., \& Volná, J. (2012, April). A content analysis of intellectual capital reporting within slovak companies. Proceedings of the 4th European Conference on Intellectual Capital, Helsinki/Finland, 363-370.

Prusak, R. (2017). The impact of the level of market competition intensity on enterprises activities in area of intellectual capital. Management, 21(2), 52.

Purohit, H., \& Tandon, K. (2017). Intellectual capital efficiency of Indian firms: An empirical analysis. IUP Journal of Knowledge Management, 15(3), 44-65.

Sarıy, M. A. İ. (2016). Entelektüel sermayenin finansal durum tablosunda raporlanması: Türkiye muhasebe standartları ve Türk vergi mevzuatı çerçevesinde bir araştırma. Niğde Üniversitesi Sosyal Bilimler Enstitüsü, Doktora Tezi, Niğde.

Singh, R. D., \& Narwal, K. P. (2016). An examination of the relationship between intellectual capital efficiency and financial performance. South Asian Journal of Management, 23(3), 78-101.

Stewart, T. A. (1997). Entelektüel Sermaye. Çev. N. Elhüseyni, İstanbul: Mess Yayınları.

Şamiloğlu, F. (2006). Entelektüel sermaye: IMKB'de hisse senetleri işlem gören bankalar üzerine bir uygulama. Muhasebe ve Finansman Dergisi, 31, 78-89.

Şamiloğlu, F., \& Akgün, A. İ. (2015). Türkiye Finansal Raporlama Standartlarına Uygun Finansal Tablolar Analizi. Bursa: Ekin Yayınevi.

Şen, i. K. (2014). Uluslararası finansal raporlama standartlarına geçişin entelektüel sermaye üzerindeki etkileri: Toprak ve toprağa dayalı ürünler sektöründe bir araştırma. Çankırı Karatekin Üniversitesi Sosyal Bilimler Enstitüsü Dergisi, 5(1), 89-108.

Ulusan, H. (2005). Maddi olmayan varlıklar ve işletme içinde yaratılan maddi olmayan varlıklar ile ilgili bir araştırma. Kocaeli Üniversitesi Sosyal Bilimler Enstitüsü Dergisi, 10(2), 87,88. 
Uzay, Ş., \& Savaş, O. (2003). Entelektüel sermayenin ölçülmesi: Mobilya sektöründe karşılaştırmalı bir uygulama örneği. Erciyes Üniversitesi Iktisadi ve Idari Bilimler Fakültesi Dergisi, 20, 163-181.

Ünal, O. (2010). Entelektüel sermayenin raporlanması ve UMS 38 maddi olmayan duran varlıklar standardı kapsamında değerlendirilmesi. Gazi Üniversitesi Ticaret ve Turizm Egitim Fakültesi Dergisi, 2, 20-39.

Vaškelienè, L. (2007). Development of organizational intellectual capital measurement methodology: Problems and solutions. Economics and Management, 165.

Veltri, S, \& Bronzetti, G. (2015). A critical analysis of the intellectual capital measuring, managing, and reporting practices in the non-profit sector: Lessons learnt from a case study. Journal of Business Ethics, 131, 311.

Yereli, A. N., \& Gerşil, G. (2005). Entelektüel sermayeyi ölçme ve raporlama yöntemleri. Celal Bayar Üniversitesi Iktisadi ve Idari Bilimler Fakültesi Yönetim ve Ekonomi Dergisi, 12(2), 28.

Yörük, N., \& Erdem, M. S. (2008). Entelektüel sermaye ve unsurlarının, iMKB'de işlem gören otomotiv sektörü firmalarının finansal performansı üzerine etkisi. Iktisadi ve İdari Bilimler Dergisi, $22(2$ ), 397-413.

Zor, İ., \& Bulut, E. (2013). Entelektüel sermayenin finansal tablolara yansıtılması. Gümüşhane Üniversitesi Sosyal Bilimler Elektronik Dergisi, 8, 96-113. 